\title{
Spillovers from Universities: Evidence from the Land-Grant Program
}

\author{
Shimeng Liu \\ Post-doctoral Research Fellow \\ Lusk Center for Real Estate \\ Sol Price School of Public Policy \\ University of Southern California \\ Los Angeles, CA 90089-0626 \\ Email: shimengl@usc.edu
}

March 2, 2015

I thank Start Rosenthal, John M. Yinger, Eleonora Patacchini, Gary Painter, Jeffrey Kubik and Jing Li for helpful comments. Any errors are my own. 


\begin{abstract}
This paper estimates the short- and long-run effects of universities on geographic clustering of economic activity, labor market composition and local productivity and presents evidence of local spillovers from universities. I treat the designation of land-grant universities in the $1860 \mathrm{~s}$ as a natural experiment after controlling for the confounding factors with a combination of synthetic control methods and event-study analyses. Three key results are obtained. First, the designation increased local population density by 6 percent within 10 years and 45 percent in 80 years. Second, the designation did not change the relative size of local manufacturing sector. Third, the designation enhanced local manufacturing output per worker by \$2136 (1840 dollars; 57 percent) in 80 years while the short-run effects were negligible. This positive effect on the productivity in non-education sectors suggests the existence of local spillovers from universities. Over an 80-year horizon, my results indicate that the increase in manufacturing productivity reflects both the impact of direct spillovers from universities and general agglomeration economies that arise from the increase in population.
\end{abstract}

Key words: Land-Grant Universities; Short- and Long-Run Effects; Spillovers JEL classification: R00, J24, N32 


\section{Introduction}

Universities are widely believed to boost growth and productivity. It is conventional wisdom that "Silicon Valley" near San Jose and Route 128 around Boston owe their status as economic centers to their proximity to Stanford and MIT (Jaffe, 1989). To date, a large literature has sought to study the linkage between academic investment, potential spillovers and economic agglomerations. ${ }^{1}$ However, much of the literature focuses on spillover effects from colleges and universities on patents, innovations and business start-ups. ${ }^{2}$ Also, the feedback effects from business activities and the common factors that affect both universities and business environment make the causal impact of colleges and universities difficult to measure. Thus, the causal effects of universities on local development remain unclear. Recently, Andersson, Quigley and Wilhelmsson $(2004,2009)$ employ Sweden's decentralization policy in higher education to investigate the impact of educational investment on productivity and innovation. Using the interaction between university endowment values and stock market shocks over time for identification, Kantor and Whalley (2014a) study the local spillovers from research universities. While important, their results only apply to the short-term.

This paper exploits a novel identification strategy to estimate the short- and long-run effects of universities on geographic clustering of economic activity, labor market composition and local productivity and presents evidence of local spillovers from universities. ${ }^{3}$ The

\footnotetext{
${ }^{1}$ See Moretti (2004a) for a review of the literature on local social returns of education.

${ }^{2}$ See, for example, Jaffe (1989), Acs, Audretsch, and Feldman (1992), Bania, Eberts, and Fogerty (1993), Beeson and Montgomery (1993), Audretsch and Feldman (1996), Anselin, Varga, and Acs (1997), Varga (2000), Adams (2002), Cohen, Nelson, and Walsh (2002), Woodward, Figueiredo, and Guimarães (2006), Abramovsky, Harrison, and Simpson (2007), Andersson, Quigley, and Wilhelmsson (2004, 2009), Aghion, Boustan, Hoxby and Vandenbussche (2009) and Hausman (2011).

${ }^{3}$ The presence of universities can lead to two types of local spillovers: direct local spillovers from research and education activity and indirect spillovers (general agglomeration economies) from a larger population that universities bring in. Direct spillovers can happen through two possible mechanisms, direct interaction between faculty and local business establishments and training of students (attraction of skilled workers) who remain in the
} 
identification strategy is that I use the designation of land-grant universities in the United States in the 1860s as a natural experiment after controlling for the confounding factors with synthetic control methods (Abadie and Gardeazabal, 2003; Abadie, Diamond and Hainmueller, 2010, 2012; Billmeier and Nannicini, 2013) and event-study analyses (Jacobson, LaLonde and Sullivan, 1993; McCrary, 2007; Kline, 2012).

The Morrill Act, which facilitates my identification strategy, was signed into law in 1862. Within several years, a land-grant university was designated in each state. ${ }^{4}$ Large amounts of federal and state appropriations were distributed to the land-grant universities annually. The historical documents suggest the designation of land-grant universities was affected by many factors other than economic considerations. Often, the determining factors were arguably exogenous. ${ }^{5}$ Recent research also indicates the geographical location of land-grant universities seems close to random (Moretti, 2004b; Kantor and Whalley, 2014b). Thus, this federal program serves as a source of exogenous variation that is vital to identify the causal effects of universities on local economies. ${ }^{6}$

One remaining issue is that "the land-grant universities were usually located in rural counties because the vocation in which the majority of Americans were engaged, and with which the land-grant colleges were most strongly identified, was agriculture" (Williams, 1991). These counties do not necessarily share the same economic attributes and trends with other counties. As a result, a comparison between the designated counties and the rest of the counties in the United

area and enhance the quality of the labor pool. Distinguishing between the two mechanisms of direct spillovers is beyond the scope of this paper.

${ }^{4}$ In 1890 and 1994, the "1890 land-grant universities" and "1994 land-grant universities" were designated. In this paper, I focus on the "1862 land-grant universities" and conduct a robust check based on the "1890 land-grant universities".

${ }^{5}$ See Nervis (1962), Edmond (1978), William (1991) and Association of Public and Land-grant Universities (2012) for a history of the land-grant program.

${ }^{6}$ Even though the land-grant colleges and universities were different from other colleges and universities in some aspects initially, they became less so over time. Thus, my results reflect the impact of colleges and universities on local economies in the long-run. 
States is likely to generate biased estimates. Also, it is hard to say the land-grant university location is purely random, and alternatives should be borne in mind. Thus, I apply a matching technique, the synthetic control method, to obtain better estimates of the impact. This method constructs a synthetic control county for each designated county. A synthetic control county is a weighted average of actual control counties where the weights are chosen to ensure the "synthetic county" closely matches the treated county. The goal of a synthetic control county is to reproduce the outcome trajectory that a designated county would have experienced in the absence of the land-grant university. Once a treated county and a synthetic control county are matched on outcome behavior and economic attributes before the designation, a discrepancy in outcome variable following the designation is interpreted as the impact of the land-grant university.

This identification strategy has several advantages. First, it pays particular attention to whether there is enough variation in the treatment within a given geographical region (that is, whether treated and comparison units share a "common support"; Billmeier and Nannicini, 2013). This means the treated and comparison counties must share a common economic environment and a sufficient number of comparison counties in the same region are required. ${ }^{7}$ In this paper, I require the designated and potential control counties are in the same state and share similar economic characteristics. I also require a sufficient number of control counties in the same state. Second, it precludes the possibility of extrapolation that regression results are often based on.

\footnotetext{
${ }^{7}$ Heckman, Ichimura, Smith, and Todd (1996) and Heckman, Ichimura, and Todd (1997) point out the failure of "common support condition" can result in a substantial bias of matching estimator. Recently, Billmeier and Nannicini (2009) show the failure of standard cross-sectional estimators to control for the existence of a common support can lead to quite far-fetched estimates.
} 
Third, it relies on identification assumptions that are weaker than assumptions in standard panel models which account for only time-invariant unobservable confounders. ${ }^{8}$

After creating a synthetic control county for each designated county, I use an event-study analysis to obtain estimates of the average impact of land-grant universities on geographic clustering of economic activity, labor market composition and local manufacturing productivity. The event-study specification describes the dynamics of the impact of land-grant universities and tests whether the land-grant designation followed any county-specific trends in outcome variables. ${ }^{9}$

A related line of research seeks to understand more generally the role of agglomeration spillovers in affecting regional growth and enhancing productivity. Marshall (1890) points out three channels through which agglomeration can enhance productivity: intermediate input sharing, labor market pooling and knowledge spillovers. Rosenthal and Strange (2008) find evidence of human capital spillovers and the attenuation pattern of such spillovers. ${ }^{10}$ This paper also contributes to this literature by presenting evidence of local spillovers from universities.

Three key results are obtained. First, the land-grant designation substantially increased population density in the designated counties, relative to the synthetic control counties. Population density grew by around 6 percent in the designated counties within a decade. The long-run effects are more profound. From the designation to 1940 (80-year impact), population density in the designated counties increased by almost 45 percent. While the short-run effect may

\footnotetext{
${ }^{8}$ Abadie, Diamond and Hainmueller (2010) show that under fairly standard conditions, the synthetic control method provides an unbiased estimator even when the underlying model allows the effects of confounding unobserved characteristics to vary with time. See Abadie, Diamond and Hainmueller (2010) for technical details. We must also notice that the synthetic control method has its own limitations. For example, it does not allow assessing the significance of the results using standard (large-sample) inferential techniques because of the usually small sample size.

${ }^{9}$ Severnini (2012) uses a combination of synthetic control methods and event-study designs to uncover the impact of hydroelectric dams and agglomeration spillovers from the dams.

${ }^{10}$ See Quigley (1998), Rosenthal and Strange (2004) and Head and Mayer (2004) for a comprehensive review of this literature.
} 
be a result of new students and newly hired faculty and staff, the long-run effect is more likely to be caused by potential spillovers from universities.

Second, the share of manufacturing workers in the population, an indicator of local labor market composition, was not affected by the land-grant designation. ${ }^{11}$ The estimates of the impact on the share of manufacturing workers in the population are small and insignificant over all periods. Although the goal of the land-grant program was to provide accessible education to agricultural and industrial society, it did not seem to generate a detectable impact on the relative size of manufacturing sector and may not be the best way to establish an industrial city. ${ }^{12}$

Third, the land-grant designation greatly enhanced local manufacturing productivity in the long run. On average, manufacturing output per worker increased by around $\$ 2,136$ (57 percent) from the late 1860 s to 1940 . This positive effect of university activities on the productivity in non-education sectors suggests the existence of spillovers from knowledge production centers - colleges and universities. To be sure, one caveat of the analysis is that I cannot separately estimate the direct spillovers from universities and the induced agglomeration economies that arise from the concentration of population. However, over an 80-year horizon, I show that the increase in manufacturing productivity reflects both the impact of direct spillovers from universities and general agglomeration economies that arise from the increase in population. Additionally, my estimates show a substantial difference between the short- and long-run effects of a large government investment in higher education, which emphasizes the importance of understanding the long-run effects of such events, as advocated by Kline (2010). Of course,

\footnotetext{
${ }^{11}$ The share of manufacturing workers in the population is the number of manufacturing workers divided by county population. The manufacturing share of employment is potentially a better indicator of labor market composition. However, I do not have data on total labor force.

${ }^{12}$ This result suggests the size of local manufacturing sector was not disproportionately affected by the land-grant designation. The absolute size of local manufacturing sector can still increase as the total population actually increased.
} 
the long-run estimates should be interpreted as the impact of the land-grant program allowing for the potentially endogenous responses of other federal and local policies that occurred in my sample period (Kline and Moretti, 2013). ${ }^{13}$ Various robust checks and placebo tests are also conducted, such as estimating the impact of the Second Morrill Act and including additional matching variables. All tests suggest my results are quite robust.

The rest of the paper is organized as follows. The next section provides the historical background of the Morrill Act and the land-grant designation. Section 3 lays out a simple model and the empirical methodology. Section 4 describes the data sources and variable construction. Empirical results are presented in Section 5, including robust checks and placebo tests. Section 6 concludes.

\section{Historical Background}

In the colonial era, higher education was only available at a few privately controlled institutions, such as Harvard and Yale, in the United States. After the Revolutionary War, the country began to organize universities as publicly controlled institutions, which were not essentially different in academic orientation from the privately controlled ones at that period. During the first half of the $19^{\text {th }}$ century, the two types of American colleges and universities, publicly and privately controlled, developed side by side.

These institutions were greatly influenced by the European universities, which primarily served the rich and offered chiefly classical and professional curricula. ${ }^{14}$ During the same period, the importance of science gained recognition gradually. Agricultural colleges started to emerge.

\footnotetext{
${ }^{13}$ A detailed discussion is in results section.

14 The courses of study consisted of large doses of Latin, Greek and moral philosophy, moderate doses of mathematics and religious subjects and only the wealthy could afford to send their young men to these institutions (Edmond, 1978).
} 
However, higher education was still unavailable to the majority of agricultural and industrial workers. The American higher education system needed to make a change.

Under this environment, Vermont Representative Justin Smith Morrill introduced the land-grant bill in Congress and the first Morrill Act was passed by the Congress and signed by President Lincoln on July 2, 1862. This act was the first major federal program to support higher education in the United States. It donated public lands to the states, the sale of which was for the "endowment, support, and the maintenance of at least one college where the leading object shall be, without excluding other scientific and classical studies and including military tactics, to teach such branches of learning as are related to agricultural and the mechanic arts, in order to promote the liberal and practical education of the industrial classes in the several pursuits and professional life. ${ }^{, 15}$ Fifty seven land-grant universities were established as a result of the first Morrill Act. The goal of these universities was "to develop at the college level instruction relating to the practical realities of an agricultural and industrial society and to offer to those belonging to the industrial classes preparation for the professions of life (Association of Public and Land-grant universities, 2012)." At the time, agriculture was the vocation in which the majority of Americans were engaged and with which the land-grant universities were identified. Therefore, land-grant universities were usually located in rural settings.

The factors that affected the land-grant designation were complicated. The historical documents suggest each college's founding was uniquely determined by a complex set of conditions and circumstances within its respective state. ${ }^{16}$ According to Williams (1991), "there

\footnotetext{
${ }^{15}$ Public lands refer to the area of land that belongs to the public and is administrated and disposed of by the federal government.

${ }^{16}$ The Morrill Act placed no restriction on the location of the land-grant colleges. In other words, the people of the various states through their respective legislatures were at liberty to locate the institution at any place they so desired (Edmond, 1978). Some states established new schools; others turned the money over to existing state or private schools.
} 
were no foregone conclusions as to which institution, or institutions, would receive the funds." There is little evidence suggesting economic considerations played a vital part during the process. In fact, the determining factors of the land-grant designation in many cases seem to be random. Pennsylvania provided a case in point. The Farmers' High School was the recipient of the landgrant funds in Pennsylvania because it was founded in 1855 as the first tax-supported agriculture college in Pennsylvania. The location of the Farmers' High School, however, was determined by a random event: General James Irwin donated two hundred acres of his farm in Centre County to the school, which undoubtedly explained why the school was established at its current location. Another example is New York State. The land-grant college was established at Ithaca because Ezra Cornell made a huge donation to the college and picked Ithaca as its location.

Recent research also supports the idea that the land-grant designation is arguably exogenous. Moretti (2004b) indicates the geographical location of land-grant universities seems close to random and the location of land-grant universities was not dependent on natural resources or other factors that could make an area wealthier. Kantor and Whalley (2014b) also suggest the land-grant university locations are independent of local economic conditions. ${ }^{17}$

In the first few decades, the development of the land-grant universities was relatively slow. State support was slim, enrollments grew slowly and student attrition remained high. The situation changed when the Hatch Act in 1887 made new federal appropriations to the land-grant universities. In 1890, the second Morrill Act was passed, made further appropriations to the universities. To receive the money, a state had to show that race was not an admission criterion or designate a separate land-grant college for blacks to receive a portion of the funds. Eighteen new land-grant universities, known as the "1890 land-grant universities," were established in the

\footnotetext{
${ }^{17}$ They argue that the agricultural experiment stations opened at pre-determined land grant university locations can be viewed as a positive shock to research virtually independent of local economic conditions. This is implicitly suggesting the land-grant university locations are independent of local economic conditions.
} 
south. In 1994, 29 Native American colleges were designated as "the 1994 land-grant universities." 18 Although the land-grant universities started as agricultural and technical schools, many have grown into large public universities that have educated almost one-fifth of all students seeking degrees in the United States.

Thus, the land-grant designation is arguably exogenous and can be viewed as a federal investment shock to local economies. The uniqueness of such a profound federal endowment program and the knowledge creation and dissemination role of universities make it especially interesting to investigate the impact of the land-grant universities. However, it is difficult to decide the comparison units because the complete information on how each land-grant university was chosen is not available. ${ }^{19}$ Thus, I explore the impact of the land-grant program with a synthetic control method and an event-study analysis.

\section{Theoretical Model and Research Design}

\subsection{Theoretical model}

The presence of universities can generate both direct and indirect effects. Direct effects can happen through two possible mechanisms, direct interaction between faculty and local businesses and training of students (attraction of skilled workers) who remain in the area and enhance the quality of local labor pool. Indirect effects are the general agglomeration economies that arise from a larger population universities bring in.

I use a simple framework from Greenstone, Hornbeck and Moretti (2010) to illustrate how direct and indirect spillovers affect local economies. Assume local firms use a production technology that uses labor and capital to produce a nationally traded good whose price is

\footnotetext{
${ }^{18}$ See Figure 1 for a detailed map of the distribution of land-grant colleges and universities.

${ }^{19}$ This is due to lack of historical documentation and the complex and unique situation in each state. Williams (1991) suggests "the complete land-grant movement history worthy of the cannons of scholarship now prevailing in the field of higher education history has not been written."
} 
normalized to one. ${ }^{20}$ Firms choose the amount of labor, L and capital, $\mathrm{K}$ to maximize the following profit function:

$$
\max _{L, K} f(A, L, K)-w L-r K,
$$

where $w$ and $r$ are input prices and $A$ is a productivity shifter (TFP). Specifically, $A$ considers all factors that affect labor and capital productivity equally, such as technology and agglomeration spillovers, if they exist. In particular, to explicitly allow for general agglomeration effects and direct spillovers from universities, I allow A to depend on local population, $N$, and the presence of universities, $U$. Also, local population is a function of the presence of universities $(N=N(U))$ :

$$
A=A(N(U), U)
$$

Define $L^{*}(w, r)$ as the optimal level of labor inputs, given the prevailing wage and cost of capital. Similarly, let $K^{*}(w, r)$ be the optimal level of capital. In equilibrium, $L^{*}$ and $K^{*}$ are set so that the marginal product of each factor is equal to its price. I allow the price of labor and capital to depend on local economic conditions. Specifically, let $w(N(U), U)$ be the inverse of the reduced-form labor supply function that links local population, $N(U)$, and the presence of universities, $U$, to the local nominal wage level, $w$. Similarly, let $r(N(U), U)$ be the inverse of the reduced-form capital supply function that links local population, $N(U)$, and the presence of universities, $U$, to capital price, $r{ }^{21}$ Then I can write the equilibrium level of profit as

$$
\begin{aligned}
& \Pi^{*}=f\left[A(N(U), U), L^{*}(w(N(U), U), r(N(U), U)), K^{*}(w(N(U), U), r(N(U), U))\right] \\
& -w(N(U), U) L^{*}(w(N(U), U), r(N(U), U))-r(N(U), U) K^{*}(w(N(U), U), r(N(U), U)) .
\end{aligned}
$$

\footnotetext{
${ }^{20}$ To simplify the model, land is considered as one type of capital here. Thus, the price of capital depends on local demand or supply conditions in my simplified model.

${ }^{21}$ Following Greenstone, Hornbeck and Moretti (2010), I allow the supply of labor and land to be less than infinitely elastic at the county level. Because land is included in capital in my model, capital is less than infinitely elastic at the county level.
} 
Consider the total derivative of profit with respect to a change in the presence (size) of universities:

$$
\begin{aligned}
& \frac{d \Pi^{*}}{d U}=\frac{\partial f}{\partial A} *\left(\frac{\partial A}{\partial N} * \frac{\partial N}{\partial U}+\frac{\partial A}{\partial U}\right)+\left(\frac{\partial w}{\partial N} * \frac{\partial N}{\partial U}+\frac{\partial w}{\partial U}\right)\left[\frac{\partial L^{*}}{\partial w}\left(\frac{\partial f}{\partial L}-w\right)+\frac{\partial K^{*}}{\partial w}\left(\frac{\partial f}{\partial K}-r\right)-L^{*}\right] \\
& +\left(\frac{\partial r}{\partial N} * \frac{\partial N}{\partial U}+\frac{\partial r}{\partial U}\right)\left[\frac{\partial L^{*}}{\partial r}\left(\frac{\partial f}{\partial L}-w\right)+\frac{\partial K^{*}}{\partial r}\left(\frac{\partial f}{\partial K}-r\right)-K^{*}\right]
\end{aligned}
$$

If firms are price takers and all factors are paid their marginal product, equation (1) simplify considerably:

$$
\frac{d \Pi^{*}}{d U}=\left(\frac{\partial f}{\partial A} *\left(\frac{\partial A}{\partial N} * \frac{\partial N}{\partial U}+\frac{\partial A}{\partial U}\right)\right)-\left(\left(\frac{\partial w}{\partial N} * \frac{\partial N}{\partial U}+\frac{\partial w}{\partial U}\right) L^{*}+\left(\frac{\partial r}{\partial N} * \frac{\partial N}{\partial U}+\frac{\partial r}{\partial U}\right) K^{*}\right)
$$

Equation (2) suggests that the effect of an increase in $U$ is the sum of two opposite effects. The first part, $\left(\frac{\partial f}{\partial A} *\left(\frac{\partial A}{\partial N} * \frac{\partial N}{\partial U}+\frac{\partial A}{\partial U}\right)\right)$, is the positive effect of universities. It contains $\frac{\partial f}{\partial A} * \frac{\partial A}{\partial U}$, the direct impact of universities, and $\frac{\partial f}{\partial A} * \frac{\partial A}{\partial N} * \frac{\partial N}{\partial U}$, the indirect spillovers of universities (general agglomeration economies). Formally, we have $\frac{\partial \mathrm{f}}{\partial \mathrm{A}}>0$ and $\frac{\partial \mathrm{N}}{\partial \mathrm{U}}>0$ by assumption, $\frac{\partial \mathrm{A}}{\partial \mathrm{U}}>0$ if direct spillovers exist, and $\frac{\partial \mathrm{A}}{\partial \mathrm{N}}>0$ if agglomeration economies exist. The second part, $-\left(\left(\frac{\partial \mathrm{w}}{\partial \mathrm{N}} *\right.\right.$ $\left.\left.\frac{\partial \mathrm{N}}{\partial \mathrm{U}}+\frac{\partial \mathrm{w}}{\partial \mathrm{U}}\right) \mathrm{L}^{*}+\left(\frac{\partial \mathrm{r}}{\partial \mathrm{N}} * \frac{\partial \mathrm{N}}{\partial \mathrm{U}}+\frac{\partial \mathrm{r}}{\partial \mathrm{U}}\right) \mathrm{K}^{*}\right)$, represents the negative effect from increases in the cost of production. Formally, this term is negative because I assume $\frac{\partial w}{\partial N}>0, \frac{\partial r}{\partial N}>0, \frac{\partial \mathrm{w}}{\partial \mathrm{U}}>0$ and $\frac{\partial \mathrm{r}}{\partial \mathrm{U}}>0$. Intuitively, an increase in $N$ or $\mathrm{U}$ is an increase in the level of economic activity in the county and therefore causes an increase in the local demand for labor and capital.

Equation (2) indicates that profits will be positive in counties with land-grant universities in the short-run if general agglomeration economies or direct spillovers from universities are large enough. This raises the attractiveness of the designated counties. In the long-run, the prices of local factors, such as land and possibly labor, are bid up. Even larger agglomeration economies 
or direct spillovers are required to keep profits positive; otherwise, an equilibrium forms such that firms and workers are indifferent between counties.

\subsection{Synthetic control method}

The Morrill Act provides arguably exogenous variation that helps identify the causal impact of colleges and universities. I then use a newly developed econometric technique, the synthetic control method, to obtain county-specific estimates. Finally, I employ an event-study analysis to obtain estimates of the average impact of the land-grant universities. This two-step procedure can be thought of as a reweighting/matching strategy to estimate treatment effects that accounts for time-varying unobserved heterogeneity. ${ }^{22}$

As discussed in Abadie and Gardeazabal (2003) and Abadie, Diamond and Hainmueller (2010, 2012), a synthetic control county is intended to reproduce the counterfactual of the case of interest in the absence of the event or intervention under scrutiny. A synthetic control county is a weighted average of potential control counties where the weights are chosen to ensure the "synthetic county" created closely matches the treated county on pre-treatment attributes including pre-treatment trends of outcome variables. Once treated and synthetic control counties are matched on outcome behavior and economic attributes before the intervention, a discrepancy in outcome variable at post-intervention periods is interpreted as treatment effects.

To provide a formal discussion of this method, suppose there is a sample of $J+1$ counties indexed by $j$, among which unit $j=1$ is the case of interest and units $j=2$ to $j=J+1$ constitute the donor pool. ${ }^{23}$ It is crucial to restrict the donor pool to counties with outcomes that are driven by the same structural process as the treated unit and that were not subject to treatment

\footnotetext{
${ }^{22}$ See Severnini (2012) for a discussion of this reweighting/matching method.

${ }^{23}$ To assume only one unit is exposed to the intervention is for expositional simplicity. In cases where multiple units are treated, one can apply this method to each treated unit separately. A donor pool is the set of potential control counties out of which the synthetic control county is constructed.
} 
shocks during the sample period of this study. In my analysis, as the land-grant designation was determined in each state, I use the rest of counties in each state as the potential comparisons.

I also assume a balanced panel, which includes a positive number of pre-intervention periods, $T_{0}$, as well as a positive number of post-intervention periods, $T_{1}$, with $T=T_{0}+T_{1}$. $W=\left(w_{2}, \ldots, w_{J+1}\right)^{\prime}$ is a $(J+1)$ weight vector, with $0 \leq w_{j} \leq 1$ for $j=2$ to $J$ and $w_{2}+\cdots+$ $w_{J+1}=1 . \mathrm{X}_{1}$ is a $(k+1)$ vector containing the values of pre-intervention characteristics of the treated county I aim to match as closely as possible, and $\mathrm{X}_{0}$ is the $(k \times J)$ matrix collecting the values of the same variables for the counties in the donor pool. $Y_{j t}$ is the outcome of county $\mathrm{j}$ at time t. The synthetic control estimator of the impact of the intervention at time $t$ is given by the comparison between the outcome of the treated unit and its synthetic control unit,

$$
Y_{1 t}-\sum_{2}^{J+1} w_{j}^{*} Y_{j t}
$$

Abadie and Gardeazabal (2003) and Abadie, Diamond and Hainmueller (2010, 2012) choose the optimal weight $w^{*}$ that minimizes

$$
\sum_{m=1}^{k} v_{m}\left(X_{1 m}-X_{0 m} W\right)^{2}
$$

where $v_{m}$ is a weight that reflects the relative importance of the matching variables in accordance to their predictive power on the outcome. An optimal choice of the vector $\mathrm{V}$ minimizes the mean squared error of the synthetic control estimator.

The matching variables are meant to be predictors of post-intervention outcomes, which are not themselves affected by the event. The matching variables I use are a set of preintervention county-specific attributes and pre-intervention outcome variables. ${ }^{24}$ Using this approach, I create a synthetic control county for each designated county. The comparison within

\footnotetext{
${ }^{24}$ See data section for details.
} 
each pair is the synthetic control estimate of the impact of the land-grant designation on the specific county.

\subsection{Event-study design}

An event-study analysis can recover the dynamics of the impact of the event and test if such an event happened in response to any county-specific trends in the outcome variable. I pool all pairs of designated and synthetic control counties, and use this method to obtain estimates of the average economic impact of land-grant universities.

Following the model used in Jacobson, LaLonde and Sullivan (1993), McCrary (2007) and Kline (2012), I consider the following econometric model:

$$
Y_{j t}=\sum_{n} \beta_{n} D_{j t}^{n}+d_{j}+d_{t}+\epsilon_{j t}
$$

where $Y_{j t}$ is the value of outcome variable, e.g. $\log$ of population density, in county $j$ in calendar year $t, d_{j}$ is a county fixed effect, $d_{t}$ is a year fixed effect, and $\epsilon_{j t}$ is an error term that may exhibit arbitrary dependence within a case but is uncorrelated with other right-hand side variables. ${ }^{25}$ The county and year fixed effects ensure my results are not subject to contamination from county time-invariant attributes and temporal shocks.

The variables $D_{j t}^{n}$ are a series of event-time dummies that equal 1 when the land-grant designation is $n$ years away in a given county. Formally, it is

$$
D_{j t}^{n}=I\left[t-e_{j}=n\right]
$$

where I[.] is an indicator function for the expression in brackets being true, and $e_{j}$ is the event time (in this case, the year of the land-grant designation in county $j$ ).

\footnotetext{
${ }^{25}$ In the empirical analysis, I also experiment with case and year fixed effects, county and region-by-year fixed effects, and county and division-by-year fixed effects. Results using case and year fixed effects are not shown to save space. A case is a pair of a treated county and its corresponding synthetic control county. Regions and divisions are defined as Census regions and divisions. There is generally more than one division in each region.
} 
Based on the model, the $\beta_{n}$ coefficients represent the time path of the outcome variable relative to the date of intervention for the treated counties conditional on the three unobserved variance components, $d_{j}, d_{t}$ and $\epsilon_{j t}$. If land-grant universities are randomly assigned to counties, the restriction $\beta_{n}=0$ should hold for all pre-intervention periods. In other words, the land-grant designation should not be, on average, preceded by county-specific trends in outcome variables. Because not all of the $\beta$ s can be identified due to the collinearity of event-time dummies and county fixed effects, I normalize $\beta_{-1}=0$, so that all post-intervention coefficients can be thought of as treatment effects. ${ }^{26}$ Each synthetic control unit is intrinsically associated with its treated counterpart, so I cluster the standard errors at the case level.

\section{Data Description}

This section describes the data sets used in this paper. County-level data on population, number of manufacturing workers, manufacturing output and other county-specific attributes are drawn from the U.S. census of population (Haines and ICPSR, 2010). County level geographic information, such as county area, latitude and longitude, comes from The National Historical Geographic Information System (NHGIS). The information on the land-grant designation is obtained from Integrated Postsecondary Education Data System (IPEDS) and Association of Public and Land-grant Universities. The market access data from 1870 are from Donaldson and Hornbeck (2012). ${ }^{27}$

The sample is restricted to counties for which data are available in each decennial census from 1840 to 1940. As a result, my basic dataset is a balanced panel of 1180 U.S. counties from

\footnotetext{
${ }^{26}$ In my analysis, the first Morrill Act was passed in 1862, and the designation of land-grant universities was mostly determined within the next several years. Because I use a decennial data set, I set year 1870 as the intervention period and normalize the coefficient of event-time dummy for 1860 to 0. In Jacobson, LaLonde, and Sullivan (1993), McCrary (2007) and Kline (2012), certain endpoint restrictions are applied, which simply state that any dynamics wear off after certain years. Because the intervention time in my analysis is the same for all treatment units, I implicitly have such endpoint restrictions.

${ }^{27}$ A market access can be viewed as a measure of how easily a county can trade with other counties.
} 
1840 through 1940. This large sample ensures my synthetic control counties are not constructed based on a thin donor pool. Some county boundaries changed over this time period; therefore, data are adjusted in later periods to maintain the 1840 county definition (Hornbeck, 2010). All dollar variables, such as manufacturing output, are reported in 1840 dollars (inflation data comes from The Federal Reserve Bank of Minneapolis).

A natural measure of economic concentration is population density. This outcome variable is intended to capture the overall impact of the land-grant designation on local economies. Other outcome variables include the share of manufacturing workers in the population and manufacturing output per worker. The share of manufacturing workers in the population is an indicator of labor market composition. The manufacturing share of employment is potentially a better indicator of labor market composition. However, I do not have data on total labor force. Manufacturing output per worker is the dollar value of manufacturing output produced divided by the number of manufacturing workers in the county. It measures local manufacturing productivity. An increase in manufacturing output per worker in the treated counties at post-intervention periods is potentially caused by spillovers from the land-grant universities.

The matching variables I use in the construction of synthetic control counties include percentage of urban population, percentage of white population, per capita agricultural output, per capita farm value, percentage of college students in the population and all pre-intervention outcome variables (1840 to 1860$).{ }^{28}$ These variables are considered as the predictors of postintervention outcomes. Other variables, such as county level market access and counties' latitudes and longitudes, are used as additional matching variables in robust checks.

\footnotetext{
${ }^{28}$ Per capita agricultural output is the total agricultural output in the county divided by the total population in the county. The data on number of workers in agricultural sector is not available.
} 


\section{Results}

\subsection{The impact on population density}

In this section, I present estimates of the impact of land-grant universities on population density. But first, I would like to discuss the possibility of comparing the designated counties with other comparison groups, such as rural counties and counties with universities. As aforementioned, it is impossible to find out complete information on the land-grant designation process because of lack of historical documentation and complexity of the situation in each state, which rules out the possibility to compare the designated counties to other candidate counties. ${ }^{29}$ Yet, most historical documents suggest land-grant universities were usually located at rural counties. In table 1, I show the mean values of population density predictors for several groups: designated counties, all counties, rural counties, counties with colleges. It is clear that the designated counties were not the deserted counties. The population density and urban population share in the designated counties were higher than the state average before the land-grant program. Thus, it would be inappropriate to simply compare the designated counties to the less populated and less urbanized counties.

It is possible to restrict my control counties to the ones with similar percentage of urban population. I show one example of such selection of control counties in Column 3 of Table $1 .^{30}$ These counties are not comparable to the designated counties on important economic attributes, especially pre-intervention population density. Besides, restricting the control counties based on certain observed attributes is just a simpler version of matching. Finally, I show the mean values of population density predictors for counties with colleges. They are not comparable, either.

\footnotetext{
${ }^{29}$ If the land-grant designation was not based on economic considerations or factors that could affect local economies, as suggested by the historical documents and other research, making such comparison may actually not be helpful if the candidate counties were not comparable economically.

${ }^{30}$ Counties with their percentage of urban population in the range of 0.0206 to $0.1706([0.0956 \pm 0.075], 0.0956$ is the mean of urban population percentage for designated counties).
} 


\subsubsection{Synthetic control method: County-specific estimates}

Several representative cases are discussed here and the others are presented graphically in Appendix A.

\section{Immediate Impact}

Figure 2, panel A, is a case of immediate impact of the land-grant designation on population density. In the figure, the time path of population density in Knox County, Tennessee and the synthetic Knox County matches very well from 1840 to the late 1860 s. After East Tennessee College ${ }^{31}$ received the land-grant funds in 1869, population density in Knox County grew much faster than its synthetic. This trend continued to 1940, the end of my sample period. The impact of the land-grant designation from the late 1860s through 1940 was approximately $1.16 \log$ points (219 percent). ${ }^{32}$

Table 2, panel A, shows pre-treatment characteristics of Knox County, its synthetic and state average. The state average does not appear to provide a suitable control. In particular, the state average of pre-intervention population density is substantially lower than Knox County. In contrast, the synthetic Knox County accurately reproduces pre-intervention population density and most other attributes of Knox County. ${ }^{33}$

\section{Lagged Impact}

A case of lagged impact is presented in Figure 2, panel B. The University of Maine was established in 1865 as a land-grant college in Penobscot County, Maine. In the first 30 years, the

\footnotetext{
${ }^{31}$ It was renamed The University of Tennessee in 1879.

${ }^{32}$ I calculate the impact of the land-grant designation from the late 1860s to 1940 as the difference of population density between the treated county and its synthetic control county in 1940, minus the difference of population density between the treated and its synthetic control county in 1860 . The latter difference is almost zero, which suggests the synthetic control county simulates the treated county well.

${ }^{33}$ The comparisons of pre-treatment characteristics between other representative counties and their corresponding synthetic control counties are presented in Table 2 and Appendix B. The general pattern is the same: The synthetic control counties provide better control units than the state average.
} 
land-grant university had no obvious impact. The population density in Penobscot County did not differ from the synthetic Penobscot County until 1890. After 1890, Penobscot County displayed faster growth in population density relative to its synthetic. The impact of the landgrant designation until 1940 was around $0.44 \log$ points (55 percent), all happened between 1890 and 1940.

\section{Indifference}

An unattractive case from a policymaking point of view is displayed in Figure 2, panel C. The time path of population density in Ingham, Michigan, and the synthetic Ingham County did not differ significantly despite the land-grant designation in the 1860s. In the figure, the impact was only $0.15 \log$ points (16 percent) until 1920 and was slightly larger after that. The county would not be much worse off without the land-grant designation.

\section{Reversion}

Figure 2, panel D portrays a disturbing case of a public investment. After the Agricultural College of Pennsylvania was designated as a land-grant university in 1863, Centre County, Pennsylvania, experienced a growth of $0.10 \log$ points $(11$ percent) from the 1860 s to 1890 , relative to its synthetic. Nevertheless, the trend reversed after 1890 and the county experienced a drop of $0.48 \log$ points (62 percent) in population density from 1890 through 1940.

\subsubsection{Event-study analysis: Pooled estimates}

To estimate the average impact of the land-grant program, I pool all pairs of treated and synthetic control counties and estimate equation (7). The coefficient estimates on the event-time dummies are presented in Table 3. I try four specifications of fixed effects: case and year fixed effects, county and year fixed effects, county and region-by-year fixed effects, and county and division-by-year fixed effects. Model 1 includes county fixed effects and year fixed effects, 
Model 2 county fixed effects and region-by-year fixed effects, and Model 3 county fixed effects and division-by-year fixed effects. Results using case and year fixed effects are not shown to save space. Model 1 is sufficient to eliminate all pre-treatment trends: the coefficient estimates on the event-time dummies for 1840 and 1850 are small and highly insignificant. This indicates the designation did not follow changes in population density - an important falsification test. ${ }^{34}$ Therefore, I focus on discussing this model and use this specification for robust checks.

First, the magnitude of the impact is remarkably large. On average, population density in designated counties grew by around $0.06 \log$ points ( 6 percent) within only ten years, compared to the synthetic controls. Short-run effects could be caused by the inflow of students, staff and faculty. From the 1860 s to 1940 (80-year impact), population density in designated counties increased by 0.37 log points ( 45 percent). The long-run effects are more likely to be caused by spillovers from universities once university size becomes stable.

Second, the difference between the short- and long-run effects is revealing. The 40 -year estimate is around $0.10 \mathrm{log}$ points (11 percent), only around one-quarter of its 80-year counterpart ( $0.37 \log$ points, or 45 percent). It implies that the impact can re-enforce itself in the long-run, a phenomenon consistent with the prediction of the theory of agglomeration economies. It is also consistent with the history of land-grant universities that their development was relatively slow in the first several decades. This suggests the assessment of large government projects require understanding of both short- and long-run effects.

\subsection{The impact on share of manufacturing workers}

The land-grant program aimed to provide accessible education to agricultural and industrial society. Also, development in manufacturing was vital in city development. Thus, a

\footnotetext{
${ }^{34}$ The coefficient estimates on pre-intervention event-time dummies are small and insignificant in all tables.
} 
natural question is how land-grant universities affected manufacturing sector. ${ }^{35}$ Using the same two-step procedure, I study the impact of the land-grant designation on the share of manufacturing workers in the population, an indicator of local labor market composition. In this and later sections, I only present the results from event-study analyses-estimates of the average impact from the land-grant designation. The county-specific estimates are available upon request.

Table 4 presents the estimates of the short- and long-run effects of the land-grant designation on percentage of manufacturing workers in the population. Similarly, I use four different models of fixed effects and the results of three models are presented in Column $1-3$. The results are essentially unchanged across specifications and I discuss Model 1. The 1910 event-time dummy is omitted because data on manufacturing workers in 1910 is missing. The coefficient of 1860 event-time dummy is normalized to 0 .

These estimates suggest the land-grant program did not change the percentage of manufacturing workers in the population. All post-intervention coefficient estimates on the event-time dummies are small and highly insignificant. On average, the share of manufacturing workers in the population grew by only 0.2 percentage points within ten years in the designated counties. The largest impact in the sample period was only 0.6 percentage points, which occurred 70 years after the designation.

These results are important from a policy-making point of view. A particular goal of the land-grant program was "to develop at the college level instruction relating to the practical realities of an agricultural and industrial society" and the initial curriculum focus in the landgrant universities was agricultural and mechanic arts related (Association of Public and Land-

\footnotetext{
${ }^{35}$ It is potentially interesting to see how the land-grant program affected agriculture. However, data forbids me to further investigate agricultural sector. Kline and Moretti (2013) find that the Tennessee Valley Authority (TVA), a large regional development program, triggers agglomeration economies in manufacturing rather than agriculture. I also believe that looking at manufacturing is a better option to provide evidence of local spillovers from universities.
} 
grant universities, 2012). However, my results suggest the size of local manufacturing sector was not disproportionately affected by the land-grant program despite the strong manufacturing orientation of the program. This yields potential implications for policy makers who seek to develop an industrial city by investing in higher education.

\subsection{The impact on manufacturing output per worker}

In this section, I present my estimates of the impact of the land-grant designation on local manufacturing productivity, as measured by manufacturing output per worker. ${ }^{36}$ Because manufacturing sector was not directly affected by the Morrill Act, enhancement in manufacturing productivity was potentially triggered by spillovers from land-grant universities.

Table 5 shows the short- and long-run effects of the land-grant designation on local manufacturing output per worker. The results are structured the same as the previous table and I discuss Model 1. The estimated short-term impact is not significant. On average, manufacturing output per worker increased by only around $\$ 102$ (7 percent) from the designation time to 1890 . However, the long-run effects are remarkable. In 1940, the estimated impact (80-year impact) increased to $\$ 2,136$ (57 percent). The long-run effects are significant at $10 \%$ level. ${ }^{37}$ This shortand long-run difference may be caused by the slow development of land-grant universities before 1890. Kantor and Whalley (2014a) provide another possible explanation: the local industries evolve over time to take advantage of the spillovers from universities in the long-run.

As aforementioned, it is difficult to estimate separately the direct spillovers from university activities and the induced agglomeration economies that arise from the concentration of population. However, over an 80-year horizon, I show that the increase in manufacturing

\footnotetext{
${ }^{36}$ Manufacturing output per worker is the dollar value of manufacturing output produced in the county divided by the number of manufacturing workers in the county. At the time, multi-site companies were not as common as today. Therefore, this measure can be a good indicator of productivity.

${ }^{37}$ A model with outcome variable in logs yields similar results.
} 
productivity reflects both the impact of direct spillovers from universities and general agglomeration economies that arise from the increase in population in a back-of-envelope calculation. In the literature, the range of estimated urbanization elasticities is between 2 percent to 5 percent. ${ }^{38}$ Combes et al. (2008) report urbanization elasticities in France that range from 2.5 to 4.7 percent depending on the number of controls included in the model. Ciccone (2002) estimates an elasticity of 4.5 percent drawing on data from several countries in Europe. Ciccone and Hall (1996) estimate an elasticity of 5 percent based on state-level data in the United States. Rosenthal and Strange (2008) estimate urbanization elasticities that are in the range of 3 to 5 percent. I take the upper bound of the estimated urbanization elasticities in the literature, 5 percent, to do a simple calculation. The estimated 80-year impact of the land-grant designation on population density is 45 percent. Thus, the implied productivity gain from general agglomeration economies is only 2.25 percent. This is only a small fraction of the estimated 80 year productivity gain in manufacturing sector caused by the land-grant designation. It suggests the effects on manufacturing productivity reflect both the direct spillovers from universities and effects of general gains from population density.

These findings are especially important when combined with the results from last section that the land-grant designation had no substantial effects on local labor market composition. It explains the existence of many college towns in the United States. College towns are the beneficiaries of spillovers from universities; however, they do not often become industrial cities. It is somewhat surprising that manufacturing output per worker rose substantially in response to the land-grant program while the relative size of manufacturing sector did not. One possible explanation is the land-grant universities generated spillovers to all sectors nearby, and did not

\footnotetext{
${ }^{38}$ An urbanization elasticity of 1 percent means doubling the nearby population increases productivity by 1 percent. This is called the urbanization effect in the agglomeration literature.
} 
disproportionately affect manufacturing. It is also possible that the aggregate measures in historical data do not allow me to identify such differential effects across sectors. This is consistent with the fact that the designated counties did not often become industrial cities.

Of course, the land-grant program was not the only spatially biased intervention in my sample period. A list of examples is federal taxation policy, environmental regulation, labor regulation, construction of federal highway system and other infrastructure projects. If the geography of other interventions is entirely uncorrelated with the land-grant program, they would not affect the interpretation of my results. This is highly unlikely. Thus, my estimates should be interpreted as the impact of the land-grant program on the designated counties, allowing for the potentially endogenous response of other federal and local policies that might have occurred in my sample period (Kline and Moretti, 2013). This does not undermine the results. Firstly, the endogenous response of other policies and their local effects can be interpreted as the indirect impact of the land-grant program. Secondly and more importantly, if the geography of other policies, such as construction of highway systems, is mainly determined by local population density, the impact of those policies is actually differenced out when I subtract the impact of general agglomeration economies from my estimated productivity enhancement in the back-of-envelope calculation. ${ }^{39}$

\subsection{Robust checks and specification issues}

I conduct additional analyses to evaluate several possible concerns. First, I use the same procedure to estimate the impact of the "1890 land-grant universities." The 1890 land-grant universities were established as a result of the Second Morrill Act in 1890. The Second Morrill

\footnotetext{
${ }^{39}$ This is based on the assumption that cities with similar population have equally developed highway systems. In the long-run, the impact of such infrastructure projects should be captured by the urbanization elasticity. Thus, when the estimated impact of general agglomeration economies (calculated based on urbanization elasticity) is subtracted, the impact of those policies should be at least partially differenced out.
} 
Act is quite different from the first act on policy target, appropriation amount and selection criteria. Thus, it is not appropriate to simply pool the "1862 land-grant universities" and the “1890 land-grant universities" and estimate an average impact. However, using the "1890 landgrant universities" has the advantage of a longer pre-intervention period. ${ }^{40}$ Moreover, the location of the "1890 land-grant universities" is mainly driven by the distribution of African Americans, which is less likely to be correlated with economic considerations or political factors that could affect economic development.

The results are presented in Table 6. In Model 1, on average, the 10-year impact of 1890 land-grant universities on population density was around $0.06 \log$ points (6 percent). ${ }^{41}$ To 1940 , the impact rose to $0.27 \mathrm{log}$ points $(31$ percent). These estimates are qualitatively the same as my previous estimates based on the "1862 land-grant universities," although less significant. ${ }^{42}$ It suggests the length of the pre-intervention periods and identification assumptions in my main specifications are not problematic.

Second, I include county level market access in 1870 as an additional matching variable and estimate the impact of "1862 land-grant universities." 43 This measure of market access is a novel measure that summarizes how easily a county can trade with other counties. Although the matching variables in my main specifications are comprehensive, it is helpful to see whether the inclusion of additional matching variables changes my conclusions. The results are reported in

\footnotetext{
${ }^{40}$ Abadie, Diamond and Hainmueller (2010) suggest a long pre-intervention period helps control for unobserved factors affecting the outcome of interest as well as for heterogeneity of the effect of the observed and unobserved factors. They show that the bias of the synthetic control estimator depends on the structure of observed and unobserved factors and that bias can be bounded by a function that goes to zero as the number of pretreatment periods increases. See Abadie, Diamond and Hainmueller (2010) for technical details.

${ }^{41}$ The Second Morrill Act was passed in 1890, so the coefficient estimate of the event-time dummy for 1890 can be viewed as an immediate impact and the coefficient estimate of event-time dummy for 1900 is the 10-year impact.

${ }^{42}$ This may be because of the smaller sample size in these regressions.

${ }^{43}$ Most land-grant universities were established before 1870. Thus, an implicit assumption here is that counties' market access had not changed from the designation time to 1870 .
} 
column 4 (Model 4) of Table 3, Table 4 and Table 5 (county and year fixed effects specification). The results are largely unchanged by the inclusion of this additional matching variable.

Third, I include the cubic function in counties' latitudes and longitudes as additional controls and estimate the impact of "1862 land-grant universities." Some may argue that counties near the treated county geographically are better control units than the rest of the counties in the state. Matching on the cubic function in counties' latitudes and longitudes ensures the treated and the synthetic control counties are geographically close. The results are reported in column 5 (Model 5) of Table 3, Table 4 and Table 5. The results are quite similar.

Fourth, I exclude the neighboring counties from the donor pool. The land-grant program may lead to displacement and spillover effects to nearby areas. These two forces work against each other and may or may not bias my results. I try a specification without adjacent counties, and the results are reported in column 6 (Model 6) of Table 3, Table 4 and Table 5. My previous conclusions still hold.

Finally, to ensure my research design captures the impact of the land-grant universities rather than some random factors or unobserved interventions, I run placebo tests. I run the same two-step procedure except now I choose the treated county randomly. My previous findings would be undermined if I obtain a similar or even greater effect when the treated counties are randomly selected (where the intervention did not take place). I run the two-step procedure 20 times. The estimated effects of artificial treatment are shown in Figure 3. The heavy solid black line is the impact of the real treatment, which is plotted for comparison purpose. It is obvious that the effect of the real treatment is larger than any placebo effects. Because I conduct the placebo tests 20 times, the probability of estimating a placebo effect as large as the true effect 
under random permutation of the intervention in my data is 5 percent, a test level typically used in conventional tests of statistical significance.

\section{Conclusions}

The success of "Silicon Valley" and Route 128 is glaring and the attempt to mimic such success has never stopped. Most recently, Cornell University, and its partner, Technion-Israel Institute of Technology, won the right to build a facility for job-spinning engineering research on Roosevelt Island in New York City, aiming to increase entrepreneurship and job growth in the city's technology sector. Despite the public attention, the precise linkage between educational investment, spillover effects and regional development remains unclear. In this paper, I seek to fill part of this gap by presenting evidence of local spillovers from universities and examining the short- and long-run effects of university activities on geographic clustering of economic activity, labor market composition and local productivity.

Several key conclusions are obtained. First, population density in the designated counties grew substantially as a result of the land-grant program. On average, population density in the designated counties rose by around 6 percent within ten years and 45 percent after 80 years, relative to the synthetic control counties. Second, the land-grant program did not change the relative size of manufacturing sector in the designated counties. Third, local manufacturing productivity, as measured by manufacturing output per worker, was greatly enhanced by the land-grant program in the long-run. Manufacturing output per worker climbed by around \$2136 (57 percent) in designated counties after 80 years. This impact on the productivity in noneducation sectors suggests the existence of spillovers from universities. Over an 80-year horizon, I estimate that the increase in manufacturing productivity reflects both the impact of direct 
spillovers from universities and general agglomeration economies that arise from the increase in population. The robust checks and placebo tests suggest these results are quite robust.

These results have broad policy implications. My results suggest that investing in higher education is not a useful policy instrument to change the relative size of manufacturing sector in cities. However, investment in higher education increases population density and enhances local productivity. This partially justifies the continuous subsidy to post-secondary education. My findings also have implications for understanding the existence of many college towns in the United States. Finally, my analysis focuses on the local level and lacks aggregate economic implications. Future research is warranted to investigate the national level impact of such interventions. 


\section{References}

Abadie, A., Diamond, A., Hainmueller, J., 2010. Synthetic Control Methods for Comparative Case Studies: Estimating the Effect of California's Tobacco Control Program, Journal of The American Statistical Association 105(490), 493-505.

Abadie, A., Diamond, A., Hainmueller, J., 2012. Comparative Politics and The Synthetic Control Method, Working Paper.

Abadie, A., Gardeazabal, J., 2003. The Economic Costs of Conflict: A Case Study of the Basque Country, The American Economic Review 93(1), 113-132.

Abramovsky, L., Harrison, R., Simpson, H., 2007. University Research and the Location of Business R\&D, Economic Journal 117(519), C114-C141.

Acs, Z.J., Audretsch, D.B., Feldman, M.P., 1992. Real Effects of Academic Research: Comment, The American Economic Review 82(1), 363-367.

Adams, J.D., 2002. Comparative localization of academic and industrial spillovers, Journal of Economic Geography 2(3), 253-278.

Aghion, P., Boustan, L., Hoxby, C., Vandenbussche, J., 2009. The Causal Impact of Education on Economic Growth: Evidence from U.S., Working Paper.

Andersson, R., Quiley, J.M., Wilhelmsson, M., 2004. University decentralization as regional policy: the Swedish experiment, Journal of Economic Geography 4(4), 371-388.

Andersson, R., Quiley, J.M., Wilhelmsson, M., 2009. Urbanization, productivity, and innovation: Evidence from investment in higher education, Journal of Urban Economics 66(1), 2-15.

Anselin, L., Varga, A., Acs, Z., 1997. Local Geographic Spillovers between University Research and High Technology Innovations, Journal of Urban Economics 42(3), 422-448.

Association of Public and Land-grant universities, The Land Grant Tradition, Washington, D.C. 2012.

Audretsch, D.B., Feldman, M.P., 1996. R\&D Spillovers and the Geography of Innovation and Production, The American Economic Review 86(3), 630-640.

Bania, N., Eberts, R.W., Fogarty, M.S., 1993. Universities and the Startup of New Companies: Can We Generalize from Route 128 and Silicon Valley?, The review of economics and statistics 75(4), 761-766.

Beeson, P., Montgomery, E., 1993. The Effects of Colleges and Universities on Local Labor Markets, The review of economics and statistics 75(4), 753-761. 
Billmeier, A., Nannicini, T., 2009. Trade Openness and Growth: Pursuing Empirical Glasnost, IMF Staff Papers, Palgrave Macmillan, 56(3), 447-475.

Billmeier, A., Nannicini, T., 2013. Assessing Economic Liberalization Episodes: A Synthetic Control Approach, Review of Economics and Statistics 95(3), 983-1001.

Ciccone, A., 2002. Agglomeration effects in Europe, European Economic Review 46, $213-227$.

Ciccone, A., Hall, R.E., 1996. Productivity and the density of economic activity, American Economic Review 86, 54-70.

Cohen, W.M., Nelson, R.R., Walsh, J.P., 2002. Links and Impacts: The Influence of Public Research on Industrial R\&D, Management Science 48(1, Special Issue on University Entrepreneurship and Technology Transfer), 1-23.

Combes, P.-P., Duranton, G., Gobillon, L., Roux, S., 2010. Estimating agglomeration effects with history, geology, and worker effects, NBER Chapters, in: Agglomeration Economics, 15-66.

Donaldson, D., Hornbeck, R., 2012. Railroads and American economic growth: a "market access" approach, Working paper.

Edmond, J.B., 1978. The Magnificent Charter: The Origin and Role of the Morrill Land-Grant Colleges and Universities, Exposition Press, New York.

Greenstone, M., Hornbeck, R., Moretti, E., 2010. Identifying Agglomeration Spillovers: Evidence from Winners and Losers of Large Plant Openings, Journal of Political Economy 118(3), 536-598.

Haines, M.R., and Inter-university Consortium for Political and Social Research. Historical, Demographic, Economic, and Social Data: The United States, 1790-2002. Ann Arbor, MI: Interuniversity Consortium for Political and Social Research.

Hausman, N., 2011. University innovation, local economic growth, and entrepreneurship, Harvard University working paper.

Head, K., Mayer, T., 2004. The empirics of agglomeration and trade, Handbook of Regional and Urban Economics 4, 2609-2669.

Heckman, J.J., Ichimura, H., Smith, J., Todd, P.E., 1996. Sources of selection bias in evaluating social programs: An interpretation of conventional measures and evidence on the effectiveness of matching as a program evaluation method, Proceedings of the National Academy of Sciences 93, 13416-13420.

Heckman, J.J., Ichimura, H., Todd, P.E., 1997. Matching as an Econometric Evaluation Estimator: Evidence from Evaluating a Job Training Programme, Review of Economic Studies 64(4), 605-54. 
Hornbeck, R., 2010. Barbed wire: Property rights and agricultural development, Quarterly Journal of Economics 125(2), 767-810.

Jacobson, L.S., LaLonde, R.J., Sullivan, D.G., 1993. Earnings Losses of Displaced Workers, The American Economic Review 83(4), 685-709.

Jaffe, A.B., 1989. Real Effects of Academic Research, The American Economic Review 79(5), 957-970.

Kantor, S., Whalley, A., 2014a. Knowledge Spillovers from Research Universities: Evidence from Endowment Value Shocks, Review of Economics and Statistics 96(1), 171-188.

Kantor, S., Whalley, A., 2014b. Research Proximity and Productivity: Long-Term Evidence from Agriculture, working paper.

Kline, P., 2010. Place Based Policies, Heterogeneity, and Agglomeration, American Economic Review 100(2), 383-87.

Kline, P., 2012. The Impact of Juvenile Curfew Laws on Arrests of Youth and Adults, American Law and Economic Review 14(1), 44-67.

Kline, P., Moretti, E., 2013. Local Economic Development, Agglomeration Economies and the Big Push: 100 Years of Evidence from the Tennessee Valley Authority*, The Quarterly Journal of Economics.

Marshall, A., 1890. Principles of Economics, Macmillan, London.

McCrary, J., 2007. The Effect of Court-Ordered Hiring Quotas on the Composition and Quality of Police, The American Economic Review 97(1), 318-353.

Moretti, E., 2004a. Human capital externalities in cities, Handbook of Regional and Urban Economics 4(51), 2243-2291.

Moretti, E., 2004b. Estimating the social return to higher education: evidence from longitudinal and repeated cross-sectional data, Journal of Econometrics 121(1-2), 175-212.

Nervis, A., 1962. The State Universities and Democracy, University of Illinois Press, Champaign, IL.

Quigley, J.M., 1998. Urban Diversity and Economic Growth, The Journal of Economic Perspectives 12(2), 127-138.

Rosenthal, S.S., Strange, W.C., 2004. Evidence on the nature and sources of agglomeration economies, Handbook of Regional and Urban Economics 4, 2119-2171. 
Rosenthal, S.S., Strange, W.C., 2008. The attenuation of human capital spillovers, Journal of Urban Economics 64(2), 373-389.

Severnini, E.R., 2012. The power of hydroelectric dams: Agglomeration spillovers, working paper.

Varga, A., 2000. Local Academic Knowledge Transfers and the Concentration of Economic Activity, Journal of Regional Science 40(2), 289-309.

Williams, R.L., 1991. The Origins of Federal Support for Higher Education, The Pennsylvania State University Press, Pennsylvania.

Woodward, D., Figueiredo, O., Guimaraes, P., 2006. Beyond the Silicon Valley: University R\&D and high-technology location, Journal of Urban Economics 60(1), 15-32. 


\begin{tabular}{lcccc}
\hline \multicolumn{4}{l}{ Table 1: Overall Population Density Predictor Means } & \\
& Designated Counties & State Average & Rural Counties & College Counties \\
\hline Log(Population density), 1840 & 3.0073 & 2.7097 & 3.3408 & 3.5899 \\
Log(Population density), 1850 & 3.3126 & 3.0548 & 3.6473 & 3.8300 \\
Log(Population density), 1860 & 3.5712 & 3.3299 & 3.8659 & 4.0069 \\
Percent of Manufacturing Workers & 0.0314 & 0.0227 & 0.0342 & 0.0385 \\
Manufacturing Output Per Worker & 1406.364 & 1516.789 & 1603.228 & 1560.1970 \\
Per Capita Agricultural Output & 58.3051 & 59.3883 & 59.3492 & 58.6351 \\
Percent of Urban Population & 0.0956 & 0.0407 & 0.0535 & 0.1330 \\
Percent of White Population & 0.8019 & 0.7974 & 0.9188 & 0.8046 \\
Per Capita Farm Value & 241.7098 & 210.2915 & 278.316 & 240.2032 \\
Per Capita College Students & 0.0030 & 0.0007 & 0.0009 & 0.0042 \\
\hline
\end{tabular}

Note. This table shows the mean values of population density predictors for several groups: designated counties, all counties, rural counties, counties with colleges. Rural counties are counties with percentage of urban population in the range of 0.0206 to 0.1706 ([0.0956 \pm 0.075$], 0.0956$ is the mean of urban population percentage for designated counties). All variables except log population density are averaged for the 1840-1860 period. Dollar variables are reported in 1840 dollars. Percent of Manufacturing Workers is the percentage of manufacturing workers in the whole population. Per Capita Agricultural Output, Per Capita Farm Value and Per Capita College Students are calculated as the total agricultural output, total farm value and total college students in the county divided by county population. 


\begin{tabular}{|c|c|c|c|}
\hline \multicolumn{4}{|c|}{ Table 2: Population Density Predictor Means } \\
\hline \multicolumn{4}{|c|}{ Panel A. Population Density Predictor Means --- Knox, Tennessee } \\
\hline & Knox, Tennessee & Synthetic Control & The State Average \\
\hline Log(Population density), 1840 & 3.3056 & 3.3014 & 2.8562 \\
\hline Log(Population density), 1850 & 3.4999 & 3.5105 & 3.0605 \\
\hline Log(Population density), 1860 & 3.7389 & 3.7298 & 3.1809 \\
\hline Percent of Manufacturing Workers & 0.0193 & 0.0161 & 0.0151 \\
\hline Manufacturing Output Per Worker & 1460.45 & 1235.61 & 1265.66 \\
\hline Per Capita Agricultural Output & 44.2339 & 52.4448 & 58.9446 \\
\hline Percent of Urban Population & 0.0000 & 0.0556 & 0.0088 \\
\hline Percent of White Population & 0.8721 & 0.7740 & 0.8052 \\
\hline Per Capita Farm Value & 167.255 & 218.273 & 174.813 \\
\hline Per Capita College Students & 0.0051 & 0.0058 & 0.0007 \\
\hline \multicolumn{4}{|c|}{ Panel B. Population Density Predictor Means --- Penobscot, Maine } \\
\hline & Penobscot, Maine & Synthetic Control & The State Average \\
\hline Log(Population density), 1840 & 2.3044 & 2.3131 & 2.8019 \\
\hline Log(Population density), 1850 & 2.6249 & 2.6325 & 2.9225 \\
\hline Log(Population density), 1860 & 2.7529 & 2.7430 & 3.0347 \\
\hline Percent of Manufacturing Workers & 0.0551 & 0.0547 & 0.0440 \\
\hline Manufacturing Output Per Worker & 1505.154 & 919.885 & 1121.29 \\
\hline Per Capita Agricultural Output & 32.3850 & 21.4897 & 42.2654 \\
\hline Percent of Urban Population & 0.2070 & 0.0777 & 0.0895 \\
\hline Percent of White Population & 0.9983 & 0.9982 & 0.9982 \\
\hline Per Capita Farm Value & 89.4920 & 60.2134 & 123.7295 \\
\hline Per Capita College Students & 0 & 0 & .0003 \\
\hline
\end{tabular}

Note. This table shows the mean values of population density predictors for two counties: Knox, Tennessee and Penobscot, Maine. All variables except log population density are averaged for the 18401860 period. Dollar variables are reported in 1840 dollars. Percent of Manufacturing Workers is the percentage of manufacturing workers in the whole population. Per Capita Agricultural Output, Per Capita Farm Value and Per Capita College Students are calculated as the total agricultural output, total farm value and total college students in the county divided by county population. 
Table 3: Short- and Long-Run Effects of 1862 Land-Grant Universities on Population Density (Dependent variable: $\log$ of population density; cluster-robust t-ratios in the parentheses)

\begin{tabular}{|c|c|c|c|c|c|c|}
\hline & Model 1 & Model 2 & Model 3 & Model 4 & Model 5 & Model 6 \\
\hline Year 1840 & $\begin{array}{r}0.0367 \\
(101)\end{array}$ & $\begin{array}{c}0.0367 \\
(0.97)\end{array}$ & 0.0367 & 0.0369 & $\begin{array}{l}0.0367 \\
(101)\end{array}$ & $\begin{array}{c}0.0184 \\
(0.40)\end{array}$ \\
\hline Year 1850 & $\begin{array}{c}0.0137 \\
(0.69)\end{array}$ & $\begin{array}{c}0.0137 \\
(0.67)\end{array}$ & $\begin{array}{r}0.0137 \\
(0.64)\end{array}$ & $\begin{array}{c}0.0138 \\
(0.70)\end{array}$ & $\begin{array}{c}0.0137 \\
(0.69)\end{array}$ & $\begin{array}{l}0.0127 \\
(0.62)\end{array}$ \\
\hline Year 1870 & $\begin{array}{c}0.0613 \\
(2.38)\end{array}$ & $\begin{array}{c}0.0613 \\
(2.29)\end{array}$ & $\begin{array}{c}0.0613 \\
(2.19)\end{array}$ & $\begin{array}{c}0.0603 \\
(2.36)\end{array}$ & $\begin{array}{c}0.0562 \\
(2.17)\end{array}$ & $\begin{array}{c}0.0692 \\
(2.64)\end{array}$ \\
\hline Year 1880 & $\begin{array}{c}0.0545 \\
(1.75)\end{array}$ & $\begin{array}{c}0.0545 \\
(1.68)\end{array}$ & $\begin{array}{c}0.0545 \\
(1.61)\end{array}$ & $\begin{array}{c}0.0508 \\
(1.71)\end{array}$ & $\begin{array}{c}0.0462 \\
(1.50)\end{array}$ & $\begin{array}{c}0.0822 \\
(2.52)\end{array}$ \\
\hline Year 1890 & $\begin{array}{c}0.0923 \\
(1.72)\end{array}$ & $\begin{array}{c}0.0923 \\
(1.65)\end{array}$ & $\begin{array}{c}0.0923 \\
(1.59)\end{array}$ & $\begin{array}{c}0.0893 \\
(1.69)\end{array}$ & $\begin{array}{c}0.0865 \\
(1.60)\end{array}$ & $\begin{array}{c}0.1210 \\
(2.07)\end{array}$ \\
\hline Year 1900 & $\begin{array}{c}0.0963 \\
(1.42)\end{array}$ & $\begin{array}{c}0.0963 \\
(1.37)\end{array}$ & $\begin{array}{c}0.0963 \\
(1.31)\end{array}$ & $\begin{array}{c}0.0924 \\
(1.38)\end{array}$ & $\begin{array}{c}0.0904 \\
(1.32)\end{array}$ & $\begin{array}{c}0.1305 \\
(1.84)\end{array}$ \\
\hline Year 1910 & $\begin{array}{c}0.1430 \\
(1.65)\end{array}$ & $\begin{array}{c}0.1430 \\
(1.58)\end{array}$ & $\begin{array}{c}0.1430 \\
(1.52)\end{array}$ & $\begin{array}{c}0.1380 \\
(1.60)\end{array}$ & $\begin{array}{c}0.1404 \\
(1.61)\end{array}$ & $\begin{array}{c}0.1671 \\
(1.85)\end{array}$ \\
\hline Year 1920 & $\begin{array}{c}0.2007 \\
(2.04)\end{array}$ & $\begin{array}{c}0.2007 \\
(1.96)\end{array}$ & $\begin{array}{c}0.2007 \\
(1.88)\end{array}$ & $\begin{array}{c}0.1952 \\
(1.99)\end{array}$ & $\begin{array}{c}0.2011 \\
(2.04)\end{array}$ & $\begin{array}{c}0.2221 \\
(2.16)\end{array}$ \\
\hline Year 1930 & $\begin{array}{c}0.3161 \\
(2.96)\end{array}$ & $\begin{array}{c}0.3161 \\
(2.85)\end{array}$ & $\begin{array}{c}0.3161 \\
(2.73)\end{array}$ & $\begin{array}{c}0.3100 \\
(2.90)\end{array}$ & $\begin{array}{c}0.3163 \\
(2.98)\end{array}$ & $\begin{array}{c}0.3155 \\
(2.80)\end{array}$ \\
\hline Year 1940 & $\begin{array}{c}0.3689 \\
(3.24)\end{array}$ & $\begin{array}{c}0.3689 \\
(3.11)\end{array}$ & $\begin{array}{c}0.3689 \\
(2.98)\end{array}$ & $\begin{array}{c}0.3614 \\
(3.16)\end{array}$ & $\begin{array}{c}0.3664 \\
(3.27)\end{array}$ & $\begin{array}{c}0.3604 \\
(3.03)\end{array}$ \\
\hline Observations & 462 & 462 & 462 & 462 & 462 & 462 \\
\hline Case FE & - & - & - & . & - & - \\
\hline County FE & 42 & 42 & 42 & 42 & 42 & 42 \\
\hline Year FE & 11 & - & - & 11 & 11 & 11 \\
\hline Region by Year FE & - & 44 & - & - & - & - \\
\hline Division by Year FE & - & - & 77 & - & - & - \\
\hline Market Access & - & - & - & Yes & - & - \\
\hline Geographic Info & - & - & - & - & Yes & - \\
\hline R-squared & 0.863 & 0.898 & 0.921 & 0.863 & 0.864 & 0.859 \\
\hline
\end{tabular}

Notes. This table presents the short- and long-run effects of the 1862 land-grant universities on population density. The estimated coefficients are the coefficients of the event-time dummies. T-ratios are based on standard errors clustered at a case level. A case is a pair of a treated county and its corresponding synthetic control county. The coefficient of the 1860 event-time dummy is normalized to 0 , so all coefficients after 1870 can be thought of as treatment effects. Market access is estimated by Donaldson and Hornbeck (2012) for year 1870. Geographic information includes the cubic function in latitude and longitude. Matching on latitudes and longitudes ensures the treated and its synthetic control near each other geographically. 
Table 4: Short- and Long-Run Effects of 1862 Land-Grant Universities on Percentage of Manufacturing Workers (Dependent variable: Percentage of Manufacturing Workers; cluster-robust t-ratios in the parentheses)

\begin{tabular}{|c|c|c|c|c|c|c|}
\hline & Model 1 & Model 2 & Model 3 & Model 4 & Model 5 & Model 6 \\
\hline Year 1840 & $\begin{array}{c}-0.0004 \\
(-0.55)\end{array}$ & $\begin{array}{c}-0.0004 \\
(-0.53)\end{array}$ & $\begin{array}{c}-0.0004 \\
(-0.50)\end{array}$ & $\begin{array}{c}-0.0004 \\
(-0.54)\end{array}$ & $\begin{array}{c}-0.0004 \\
(-0.55)\end{array}$ & $\begin{array}{c}0.0032 \\
(0.68)\end{array}$ \\
\hline Year 1850 & $\begin{array}{c}0.0006 \\
(0.48)\end{array}$ & $\begin{array}{c}0.0006 \\
(0.46)\end{array}$ & $\begin{array}{c}0.0006 \\
(0.44)\end{array}$ & $\begin{array}{c}0.0006 \\
(0.48)\end{array}$ & $\begin{array}{c}0.0006 \\
(0.48)\end{array}$ & $\begin{array}{c}0.0042 \\
(0.82)\end{array}$ \\
\hline Year 1870 & $\begin{array}{c}0.0019 \\
(0.36)\end{array}$ & $\begin{array}{c}0.0019 \\
(0.35)\end{array}$ & $\begin{array}{c}0.0019 \\
(0.33)\end{array}$ & $\begin{array}{c}0.0014 \\
(0.27)\end{array}$ & $\begin{array}{c}0.0019 \\
(0.36)\end{array}$ & $\begin{array}{l}0.0126 \\
(2.39)\end{array}$ \\
\hline Year 1880 & $\begin{array}{c}0.0018 \\
(0.35)\end{array}$ & $\begin{array}{c}0.0018 \\
(0.34)\end{array}$ & $\begin{array}{c}0.0018 \\
(0.32)\end{array}$ & $\begin{array}{c}0.0005 \\
(0.09)\end{array}$ & $\begin{array}{c}0.0018 \\
(0.35)\end{array}$ & $\begin{array}{c}0.0065 \\
(1.17)\end{array}$ \\
\hline Year 1890 & $\begin{array}{c}0.0032 \\
(0.60)\end{array}$ & $\begin{array}{c}0.0032 \\
(0.57)\end{array}$ & $\begin{array}{c}0.0032 \\
(0.55)\end{array}$ & $\begin{array}{c}0.0010 \\
(0.15)\end{array}$ & $\begin{array}{c}0.0032 \\
(0.60)\end{array}$ & $\begin{array}{c}0.0054 \\
(0.71)\end{array}$ \\
\hline Year 1900 & $\begin{array}{c}-0.0008 \\
(-0.14)\end{array}$ & $\begin{array}{c}-0.0008 \\
(-0.14)\end{array}$ & $\begin{array}{c}-0.0008 \\
(-0.13)\end{array}$ & $\begin{array}{c}-0.0012 \\
(-0.20)\end{array}$ & $\begin{array}{c}-0.0008 \\
(-0.14)\end{array}$ & $\begin{array}{c}0.0040 \\
(0.54)\end{array}$ \\
\hline Year 1920 & $\begin{array}{c}0.0031 \\
(0.30)\end{array}$ & $\begin{array}{l}0.0031 \\
(0.29)\end{array}$ & $\begin{array}{c}0.0031 \\
(0.27)\end{array}$ & $\begin{array}{c}0.0031 \\
(0.29)\end{array}$ & $\begin{array}{c}0.0031 \\
(0.30)\end{array}$ & $\begin{array}{l}0.0071 \\
(0.71)\end{array}$ \\
\hline Year 1930 & $\begin{array}{c}0.0059 \\
(0.53)\end{array}$ & $\begin{array}{c}0.0059 \\
(0.51)\end{array}$ & $\begin{array}{c}0.0059 \\
(0.48)\end{array}$ & $\begin{array}{c}0.0066 \\
(0.58)\end{array}$ & $\begin{array}{c}0.0059 \\
(0.53)\end{array}$ & $\begin{array}{c}0.0095 \\
(0.96)\end{array}$ \\
\hline Year 1940 & $\begin{array}{c}-0.0030 \\
(-0.38)\end{array}$ & $\begin{array}{c}-0.0030 \\
(-0.36)\end{array}$ & $\begin{array}{c}-0.0030 \\
(-0.35)\end{array}$ & $\begin{array}{c}-0.0023 \\
(-0.29)\end{array}$ & $\begin{array}{c}-0.0030 \\
(-0.38)\end{array}$ & $\begin{array}{c}-0.0008 \\
(-0.12)\end{array}$ \\
\hline Observations & 394 & 394 & 394 & 394 & 394 & 394 \\
\hline Case FE & - & - & - & - & - & - \\
\hline County FE & 40 & 40 & 40 & 40 & 40 & 40 \\
\hline Year FE & 10 & - & - & 10 & 10 & 10 \\
\hline Region by Year FE & - & 40 & - & - & - & - \\
\hline Division by Year FE & - & - & 70 & - & - & - \\
\hline Market Access & - & - & - & Yes & - & - \\
\hline Geographic Info & - & - & - & - & Yes & - \\
\hline $\mathrm{R}$-squared & 0.772 & 0.806 & 0.843 & 0.771 & 0.772 & 0.679 \\
\hline
\end{tabular}

Notes. This table presents the short- and long-run effects of the 1862 land-grant universities on the percentage of manufacturing workers in the whole population. The estimated coefficients are the coefficients of the event-time dummies. T-ratios are based on standard errors clustered at a case level. A case is a pair of a treated county and its corresponding synthetic control county. The coefficient of the 1860 event-time dummy is normalized to 0 , so all coefficients after 1870 can be thought of as treatment effects. Data on number of manufacturing workers in 1910 is missing. Market access is estimated by Donaldson and Hornbeck (2012) for year 1870. Geographic information includes the cubic function in latitude and longitude. Matching on latitudes and longitudes ensures the treated and its synthetic control near each other geographically. 


\begin{tabular}{|c|c|c|c|c|c|c|}
\hline & Model 1 & Model 2 & Model 3 & Model 4 & Model 5 & Model 6 \\
\hline Year 1850 & $\begin{array}{c}0.1642 \\
(0.33)\end{array}$ & $\begin{array}{c}0.1642 \\
(0.32)\end{array}$ & $\begin{array}{c}0.1642 \\
(0.30)\end{array}$ & $\begin{array}{c}-0.0781 \\
(-0.17)\end{array}$ & $\begin{array}{c}0.0185 \\
(0.04)\end{array}$ & $\begin{array}{c}-9.3295 \\
(-0.51)\end{array}$ \\
\hline Year 1870 & $\begin{array}{c}-100.1964 \\
(-1.32)\end{array}$ & $\begin{array}{c}-100.1964 \\
(-1.26)\end{array}$ & $\begin{array}{c}-100.1964 \\
(-1.20)\end{array}$ & $\begin{array}{c}-102.4561 \\
(-1.36)\end{array}$ & $\begin{array}{c}-99.0800 \\
(-1.39)\end{array}$ & $\begin{array}{c}-88.5941 \\
(-1.20)\end{array}$ \\
\hline Year 1880 & $\begin{array}{c}-77.2241 \\
(-0.67)\end{array}$ & $\begin{array}{c}-77.2241 \\
(-0.64)\end{array}$ & $\begin{array}{c}-77.2241 \\
(-0.61)\end{array}$ & $\begin{array}{c}-71.6221 \\
(-0.63)\end{array}$ & $\begin{array}{c}-111.2368 \\
(-0.93)\end{array}$ & $\begin{array}{c}-88.4847 \\
(-0.71)\end{array}$ \\
\hline Year 1890 & $\begin{array}{c}101.7654 \\
(0.88)\end{array}$ & $\begin{array}{c}101.7654 \\
(0.85)\end{array}$ & $\begin{array}{c}101.7654 \\
(0.80)\end{array}$ & $\begin{array}{c}99.8716 \\
(0.89)\end{array}$ & $\begin{array}{c}69.7250 \\
(0.58)\end{array}$ & $\begin{array}{c}112.6582 \\
(1.02)\end{array}$ \\
\hline Year 1900 & $\begin{array}{c}42.5077 \\
(0.17)\end{array}$ & $\begin{array}{c}42.5077 \\
(0.16)\end{array}$ & $\begin{array}{c}42.5077 \\
(0.15)\end{array}$ & $\begin{array}{c}65.8602 \\
(0.25)\end{array}$ & $\begin{array}{c}-7.8095 \\
(-0.03)\end{array}$ & $\begin{array}{c}76.9851 \\
(0.29)\end{array}$ \\
\hline Year 1920 & $\begin{array}{c}733.1091 \\
(1.52)\end{array}$ & $\begin{array}{c}733.1091 \\
(1.45)\end{array}$ & $\begin{array}{c}733.1091 \\
(1.38)\end{array}$ & $\begin{array}{c}753.8355 \\
(1.55)\end{array}$ & $\begin{array}{c}628.1318 \\
(1.29)\end{array}$ & $\begin{array}{c}698.9945 \\
(1.44)\end{array}$ \\
\hline Year 1930 & $\begin{array}{c}1,261.7632 \\
(2.03)\end{array}$ & $\begin{array}{c}1,261.7632 \\
(1.94)\end{array}$ & $\begin{array}{c}1,261.7632 \\
(1.85)\end{array}$ & $\begin{array}{c}1,323.9923 \\
(2.11)\end{array}$ & $\begin{array}{c}1,229.3784 \\
(1.96)\end{array}$ & $\begin{array}{c}1,231.3278 \\
(1.99)\end{array}$ \\
\hline Year 1940 & $\begin{array}{c}2,136.4186 \\
\quad(1.80)\end{array}$ & $\begin{array}{c}2,136.4186 \\
\quad(1.73)\end{array}$ & $\begin{array}{c}2,136.4186 \\
\quad(1.64)\end{array}$ & $\begin{array}{c}2,201.4412 \\
\quad(1.86)\end{array}$ & $\begin{array}{l}2,125.7498 \\
\quad(1.78)\end{array}$ & $\begin{array}{c}2,178.6922 \\
\quad(1.91)\end{array}$ \\
\hline Observations & 332 & 332 & 332 & 332 & 332 & 332 \\
\hline Case FE & - & - & - & - & - & - \\
\hline County FE & 38 & 38 & 38 & 38 & 38 & 38 \\
\hline Year FE & 9 & - & - & 9 & 9 & 9 \\
\hline Region by Year FE & - & 36 & - & - & - & - \\
\hline Division by Year FE & - & - & 63 & - & - & - \\
\hline Market Access & - & - & - & Yes & - & - \\
\hline Geographic Info & - & - & - & - & Yes & - \\
\hline R-squared & 0.618 & 0.694 & 0.776 & 0.616 & 0.620 & 0.615 \\
\hline
\end{tabular}

Notes. This table presents the short- and long-run effects of the 1862 land-grant universities on manufacturing output per worker. The estimated coefficients are the coefficients of the event-time dummies. T-ratios are based on standard errors clustered at a case level. A case is a pair of a treated county and its corresponding synthetic control county. The coefficient of the 1860 event-time dummy is normalized to 0 , so all coefficients after 1870 can be thought of as treatment effects. Data on manufacturing output in 1840 and 1910 is missing. Market access is estimated by Donaldson and Hornbeck (2012) for year 1870. Geographic information includes the cubic function in latitude and longitude. Matching on latitudes and longitudes ensures the treated and its synthetic control near each other geographically. 
Table 6: Short- and Long-Run Effects of 1890 Land-Grant Universities on Population Density (Dependent variable: log of population density; cluster-robust t-ratios in the parentheses)

\begin{tabular}{lccc}
\hline & Model 1 & Model 2 & Model 3 \\
\hline & & & \\
Year 1840 & 0.0032 & 0.0032 & 0.0032 \\
Year 1850 & $(0.10)$ & $(0.09)$ & $(0.09)$ \\
& -0.0032 & -0.0032 & -0.0032 \\
Year 1860 & $(-0.07)$ & $(-0.07)$ & $(-0.07)$ \\
& -0.0288 & -0.0288 & -0.0288 \\
Year 1870 & $(-1.18)$ & $(-1.12)$ & $(-1.09)$ \\
& -0.0461 & -0.0461 & -0.0461 \\
Year 1890 & $(-0.89)$ & $(-0.85)$ & $(-0.82)$ \\
& 0.0339 & 0.0339 & 0.0339 \\
Year 1900 & $(1.00)$ & $(0.94)$ & $(0.92)$ \\
& 0.0642 & 0.0642 & 0.0642 \\
Year 1910 & $(1.39)$ & $(1.32)$ & $(1.28)$ \\
& 0.1438 & 0.1438 & 0.1438 \\
Year 1920 & $(1.58)$ & $(1.50)$ & $(1.45)$ \\
& 0.1742 & 0.1742 & 0.1742 \\
Year 1930 & $(1.38)$ & $(1.31)$ & $(1.27)$ \\
& 0.2609 & 0.2609 & 0.2609 \\
Year 1940 & $(1.51)$ & $(1.43)$ & $(1.39)$ \\
& 0.2652 & 0.2652 & 0.2652 \\
Observations & $(1.39)$ & $(1.32)$ & $(1.28)$ \\
Case FE & & & \\
County FE & 242 & 242 & - \\
Year FE & - & - & 22 \\
Region by Year FE & 22 & 22 & - \\
Division by Year FE & 11 & - & - \\
R-squared & - & - & 44 \\
\hline Not Thi & - & 0.850 & 0.927 \\
\hline
\end{tabular}

Notes. This table presents the short- and long-run effects of the 1890 land-grant universities on population density. The estimated coefficients are the coefficients of the event-time dummies. Tratios are based on standard errors clustered at a case level. A case is a pair of a treated county and its corresponding synthetic control county. The coefficient of the 1880 event-time dummy is normalized to 0 , so all coefficients after 1890 can be thought of as treatment effects. 
Figure 1. U.S. Land-Grant Colleges and Universities

USDA United States Department of Agriculture
Cooperative State Research, Education, and Extension Service

\section{Land-Grant Colleges and Universities}

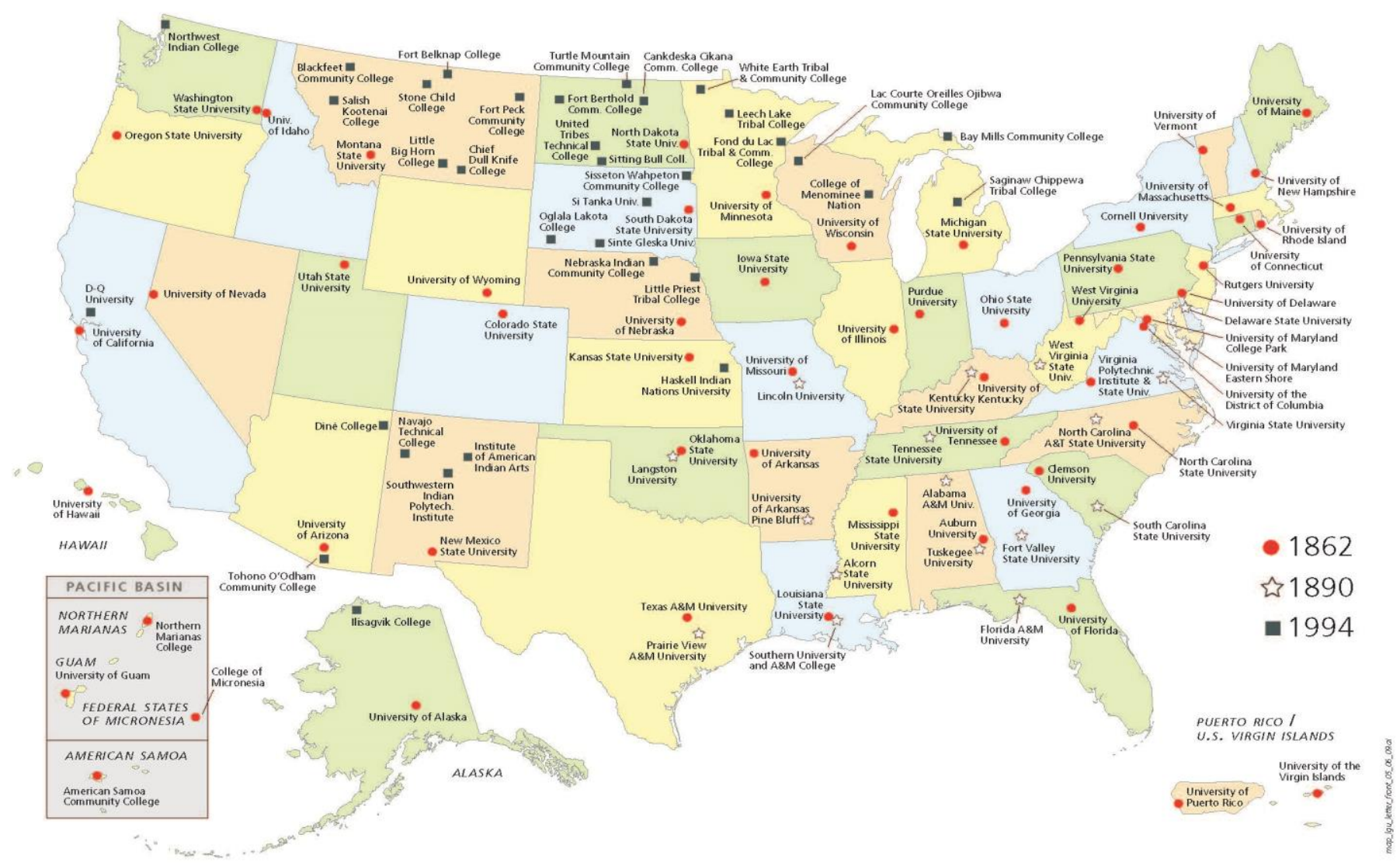

Note. Picture source: Association of Public and Land-grant universities, The Land Grant Tradition, Washington, D.C. 2012 


\section{Figure 2. Impact of Land-Grant Universities on Population Density}

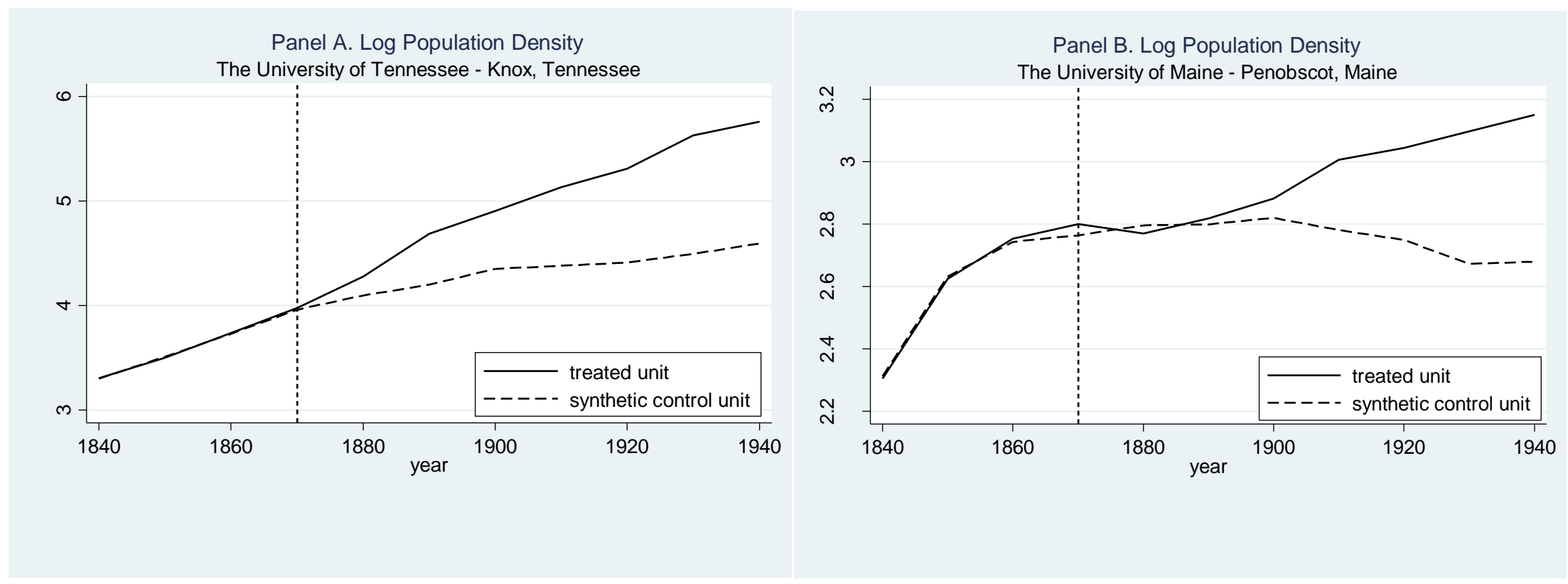

Note. These two panels plot the log population density from 1840 to 1940 for two counties: Knox, Tennessee (Panel A) and Penobscot, Maine (Panel B). The dashed vertical line shows the decade in which the new land-grant university was designated. The solid line displays the observed time series of log population density for the designated county and the dashed line presents the predicted time series of the corresponding synthetic control county. In Panel A, the new landgrant university has an immediate positive impact on population density. In Panel B, the new land-grant university has a lagged positive impact on population density. 


\section{Figure 2-Continued. Impact of Land-Grant Universities on Population Density}

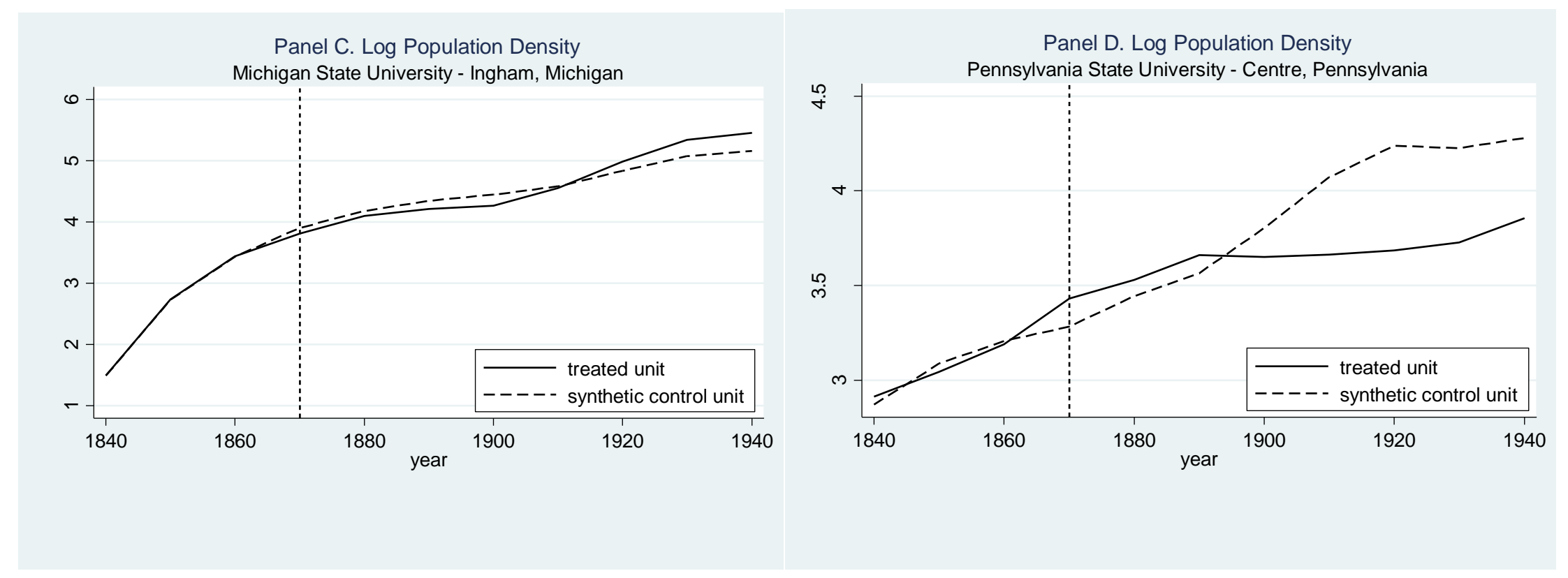

Note. These two panels plot the log population density from 1840 to 1940 for two counties: Ingham, Michigan (Panel C) and Centre, Pennsylvania (Panel D). The dashed vertical line shows the decade in which the new land-grant university was designated. The solid line displays the observed time series of log population density for the designated county and the dashed line presents the predicted time series of the corresponding synthetic control county. In Panel C, the new land-grant university does not appear to have huge impact on population density. In Panel D, the new land-grant university has a slightly positive impact on population density at first, but the trend reverses at later periods. 
Figure 3. Impact of Land-Grant Colleges and Universities on Population Density Placebo Tests

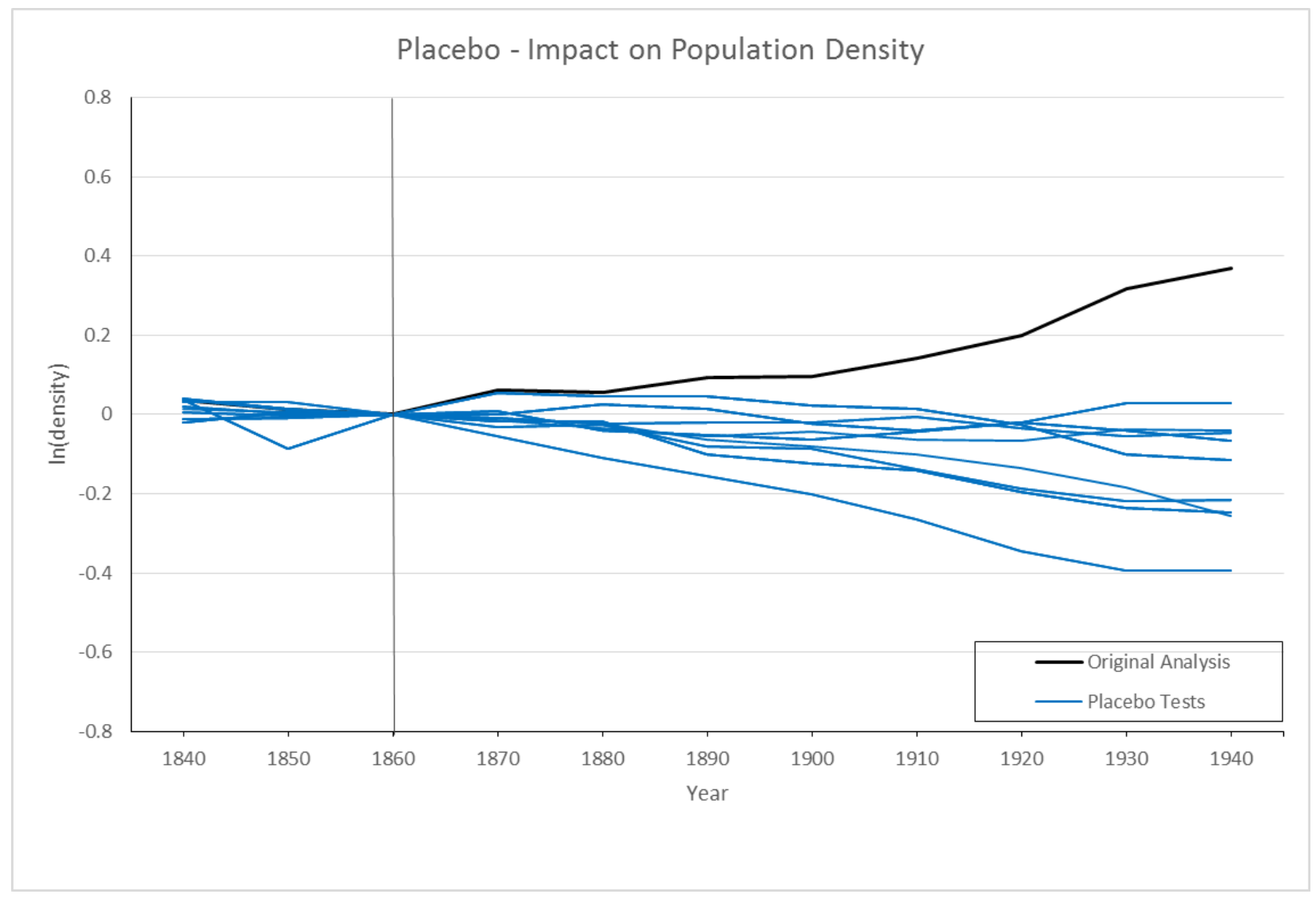

Note. This figure plots the estimates of placebo tests with 1862 land-grant colleges and universities. It graphs estimated coefficients of the event-time dummies with actual and artificially assigned treatments (county fixed effects and year fixed effects). The vertical solid line at 1860 facilitates the comparison of the dynamics before and after the treatment. The thick solid black line displays the actual effects of a new land-grant university. The thin solid blue lines present the effects with artificially treated counties. I run placebo tests 20 times (20 thin solid blue lines). 


\section{Appendix A. Impact of Land-Grant Universities on Population Density}
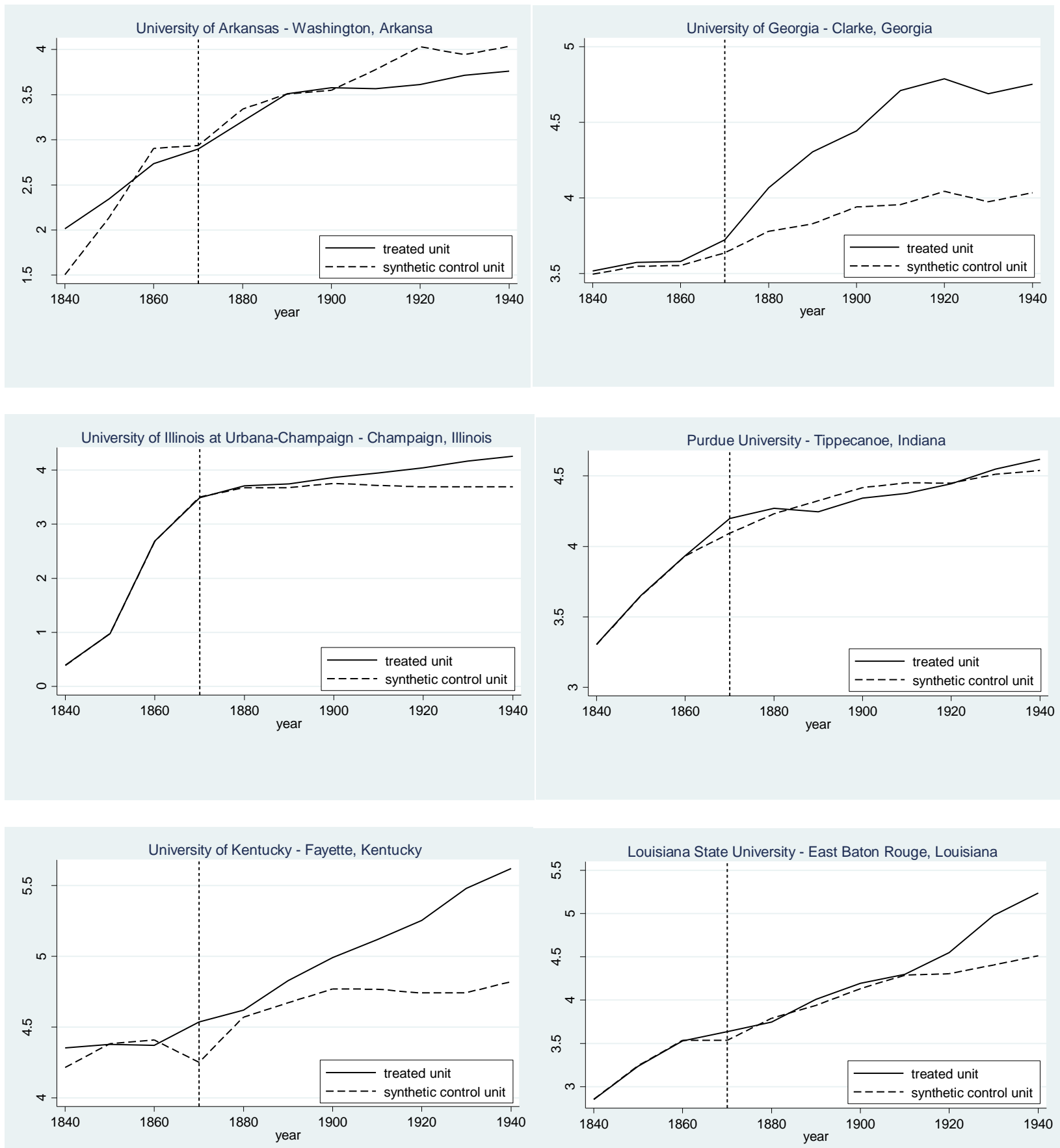


\section{Appendix A-Continued. Impact of Land-Grant Universities on Population Density}
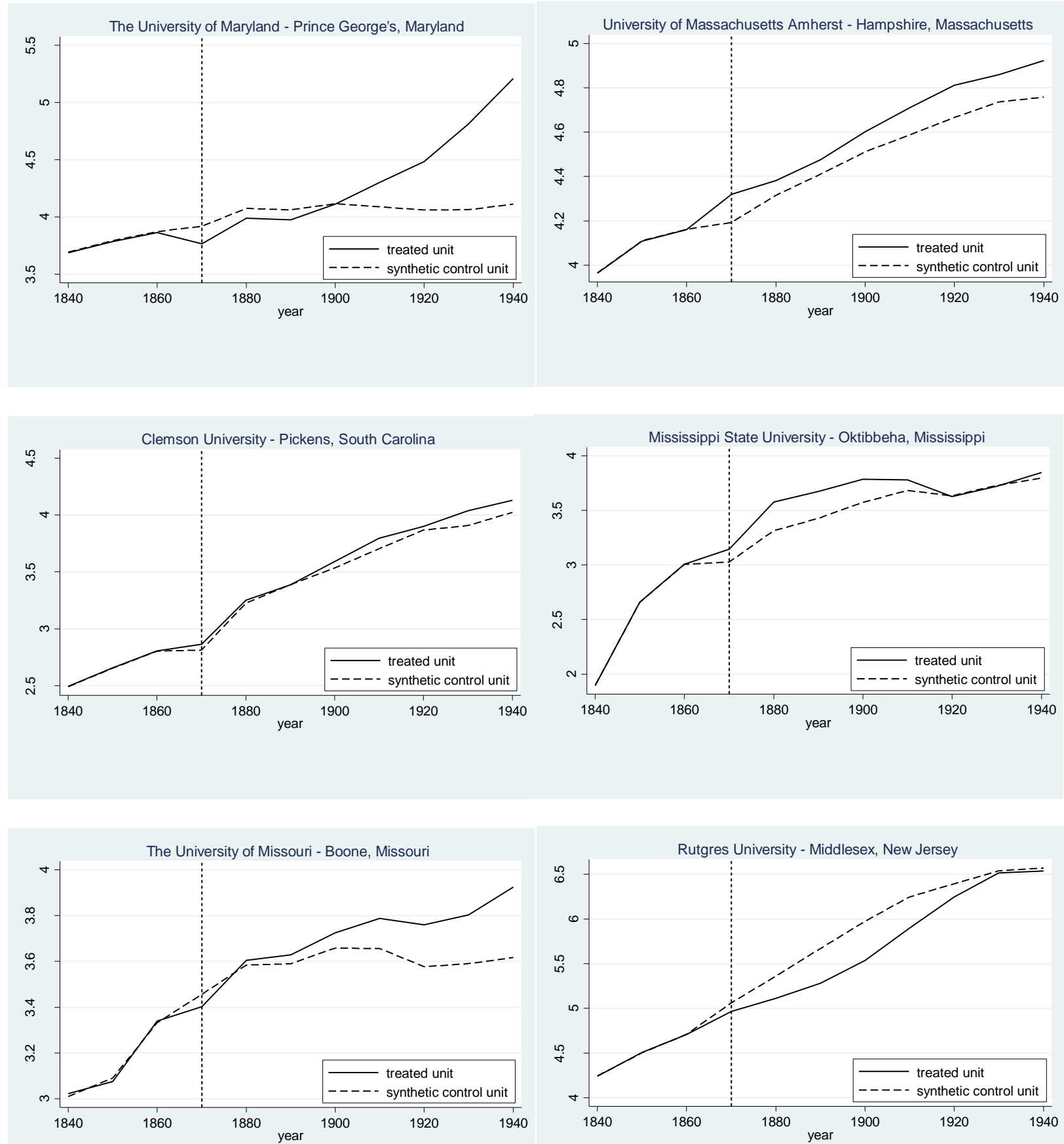


\section{Appendix A-Continued. Impact of Land-Grant Universities on Population Density}
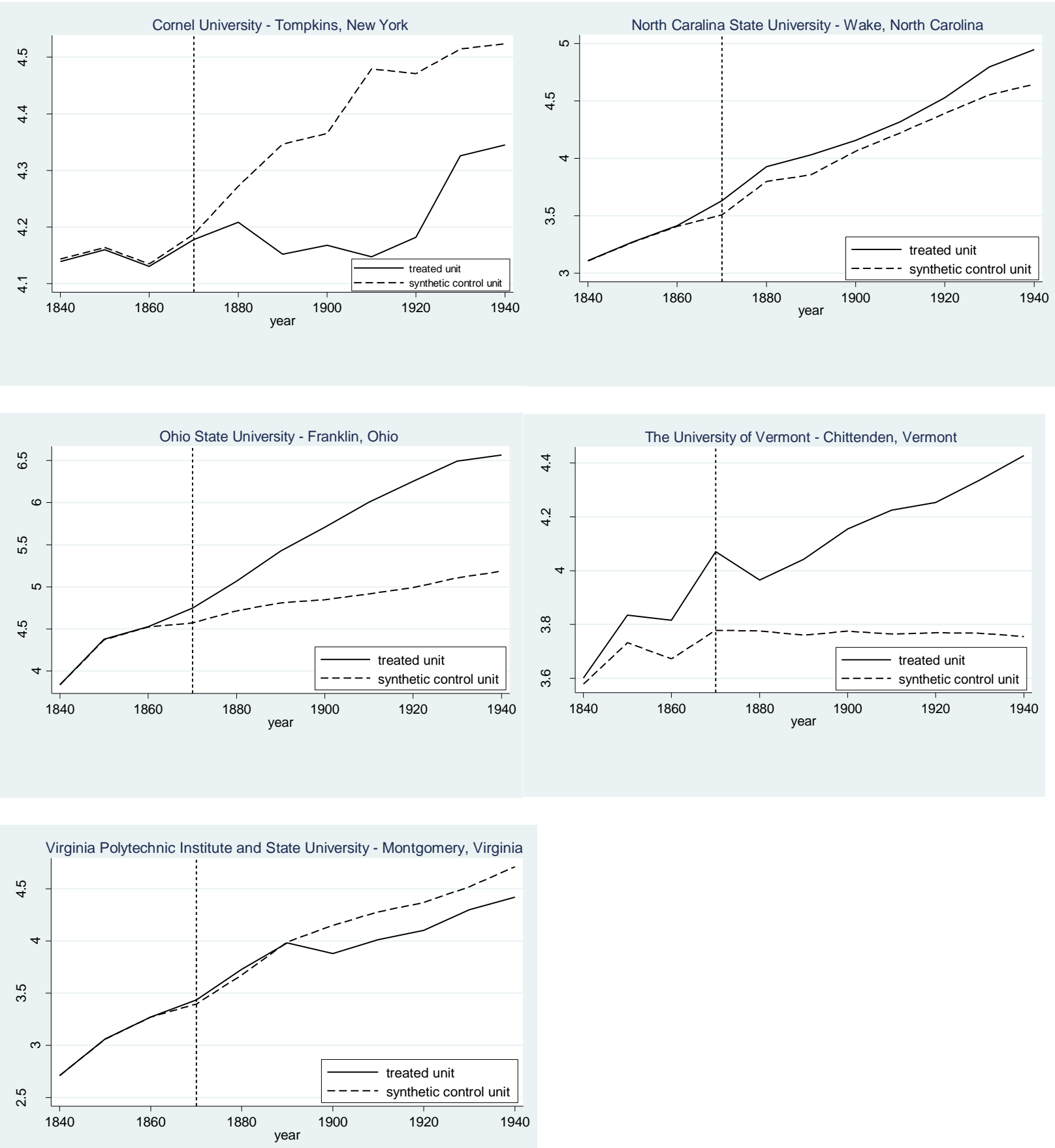


\begin{tabular}{|c|c|c|c|}
\hline \multicolumn{4}{|c|}{ Appendix B: Population Density Predictor Means } \\
\hline \multicolumn{4}{|c|}{ 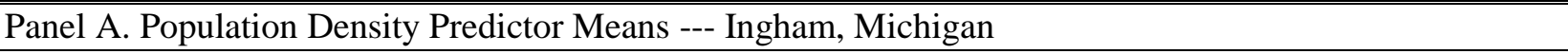 } \\
\hline & Ingham, Michigan & Synthetic Control & The State Average \\
\hline Log(Population density), 1840 & 1.4936 & 1.4919 & 1.8064 \\
\hline $\log ($ Population density), 1850 & 2.7335 & 2.7316 & 2.6464 \\
\hline $\log ($ Population density), 1860 & 3.4366 & 3.4340 & 3.3702 \\
\hline Percent of Manufacturing Workers & 0.0108 & 0.0420 & 0.0287 \\
\hline Manufacturing Output Per Worker & 1579.30 & 1657.48 & 1822.13 \\
\hline Per Capita Agricultural Output & 39.42 & 39.43 & 44.57 \\
\hline Percent of Urban Population & 0.0588 & 0.1251 & 0.0444 \\
\hline Percent of White Population & 0.9982 & 0.9894 & 0.9916 \\
\hline Per Capita Farm Value & 182.76 & 165.80 & 198.35 \\
\hline Per Capita College Students & 0 & 0.0005 & 0.0006 \\
\hline \multicolumn{4}{|c|}{ Panel B. Population Density Predictor Means --- Centre, Pennsylvania } \\
\hline & Centre, Pennsylvania & Synthetic Control & The State Average \\
\hline Log(Population density), 1840 & 2.9140 & 2.8722 & 3.4223 \\
\hline $\log ($ Population density), 1850 & 3.0448 & 3.0891 & 3.7155 \\
\hline Log(Population density), 1860 & 3.1898 & 3.2085 & 3.9396 \\
\hline Percent of Manufacturing Workers & 0.0495 & 0.0252 & 0.0460 \\
\hline Manufacturing Output Per Worker & 1276.65 & 1460.35 & 1473.41 \\
\hline Per Capita Agricultural Output & 58.1829 & 62.0971 & 52.23 \\
\hline Percent of Urban Population & 0 & 0.0036 & 0.0736 \\
\hline Percent of White Population & 0.9884 & 0.9956 & 0.9847 \\
\hline Per Capita Farm Value & 274.6277 & 266.6617 & 258.99 \\
\hline Per Capita College Students & 0 & 0 & .0008 \\
\hline
\end{tabular}

Note. This table shows the mean values of population density predictors for two counties: Ingham, Michigan and Centre, Pennsylvania. All variables except log population density are averaged for the 18401860 period. Dollar variables are reported in 1840 dollars. Percent of Manufacturing Workers is percentage of manufacturing workers in whole population. Per Capita Agricultural Output, Per Capita Farm Value and Per Capita College Students are calculated as the total agricultural output, total farm value and total college students in the county divided by county population. 